\title{
LICHENS AND LICHENICOLOUS FUNGI OF MAGURSKI NATIONAL PARK (POLAND, WESTERN CARPATHIANS)
}

\author{
Urszula BielczyK ${ }^{1}$, Pawel Czarnota, Martin Kukwa, Lucyna Śliwa, \\ Robert Kościelniak, Laura Betleja, Ryszard KoziK, Beata Krzewicka, \\ Mariusz Hachulka, Edyta Adamska, Michą Węgrzyn, Dominika Bielec, \\ Adam Flakus, Beata Guzow-Krzemińska, Katarzyna Kolanko, Joanna KoziK, \\ Grzegorz LeŚniański, Maja Lisowska, Magdalena Oset, Piotr OsyczKa, \\ Katarzyna Pietrzykowska-Urban, Anna Sadowska-DeŚ, Agnieszka SŁaby, \\ Elżbieta Studzińska-Sroka, Karina Wilk, Piotr T. Zaniewski \\ \& DARIA ZARABSKA-BOŻEJEWICZ
}

\begin{abstract}
The paper lists 337 species from Magurski National Park (MNP): 314 lichens, 18 lichenicolous fungi, four saprotrophic fungi and one lichenicolous myxomycete; 112 of them are new for MNP, 75 are reported for the first time for the Beskid Niski Mts, and two are new for Poland. Selected species are accompanied by taxonomic notes and remarks on their distribution in Poland and other Carpathian ranges. First records of Intralichen lichenicola, Burgoa angulosa and Verrucaria policensis and a second record of Epigloea urosperma are given for the whole Carpathian range, and Fuscidea arboricola was recorded for the first time in the Western Carpathians. Halecania viridescens and Mycomicrothelia confusa are new for the Polish Carpathians. The records of Absconditella pauxilla, Collema crispum, Licea parasitica and Rinodina griseosoralifera in MNP are their second known localities for the range. 93 species, mainly rare or threatened in Poland, were reported from MNP in the $20^{\text {th }}$ century but were not refound.
\end{abstract}

Key words: lichenized fungi, saprotrophic fungi, myxomycete, lichen diversity, new records, rare species, Beskid Niski Mts

Urszula Bielczyk, Robert Kościelniak, Laura Betleja \& Ryszard Kozik, Institute of Biology, Pedagogical University of Cracow, Podchorążych 2,30-84Kraków,Poland; e-mail:bielczyk@up.krakow.pl,rkosciel@up.krakow.pl, lbetleja@up.krakow.pl,ryszardkozik@gmail.com

Pawet Czarnota, Department of Agroecology, Faculty of Biology and Agriculture, University of Rzeszów, Ćwiklińskiej 1a, 35-601 Rzeszów, Poland; e-mail: pawczarnota@poczta.onet.pl

Martin Kukwa \& Magdalena Oset, Department of Plant Taxonomy and Nature Conservation, University of Gdańsk, Wita Stwosza 59,80-308Gdańsk, Poland; e-mail:dokmak@ug.edu.pl,magdalenasyrek@wp.pl

Lucyna Śliwa, Beata Krzewicka, Adam Flakus \& Karina Wilk, Laboratory of Lichenology, W. Szafer Institute of Botany, Polish Academy of Sciences, Lubicz 46, 31-512 Kraków,Poland; e-mail: l.sliwa@botany.pl, b.krzewicka@botany.pl, a.flakus@botany. pl,kwilk@botany.pl

Mariusz Hachułka, Department of Algology and Mycology, University of Łódź, Banacha 12/16, 90-237 Eódź, Poland; e-mail: m.hachulka@poczta.fm

Edyta Adamska, Chair of Geobotany and Landscape Planning Faculty of Biology and Environment Protection, Nicolaus Copernicus University, Lwowska 1,87-100 Toruń, Poland; e-mail: adamska@umk.pl

Michat Wegrzyn, Piotr Osyczka \& Agnieszka Staby, Z. Czeppe Department of Polar Research and Documentation, Institute of Botany, Jagiellonian University, Kopernika 27,31-501Kraków, Poland; e-mail: michal.wegrzyn@uj.edu.pl,piotr.osyczka@ uj.edu.pl,a.slaby@uj.edu.pl

Dominika Bielec, Malczewskiego 5/61,43-300 Bielsko-Biała, Poland; e-mail: dbielec@poczta.fm

Beata Guzow-Krzemińska, Department of Molecular Biology, University of Gdańsk, Wita Stwosza 59, 80-308 Gdańsk, Poland; e-mail: beatagk@biotech.univ.gda.pl

Katarzyna Kolanko, Institute of Biology, University of Biatystok, Świerkowa 20B, 15-950 Biatystok, Poland; e-mail: sing1@op.pl Joanna Kozik, Pieniny National Park, Jagiellońska 107B, 34-450 Krościenko n/Dunajcem, Poland; e-mail: asiakozik@o2.pl

1 Corresponding author 
Grzegorz Leśniański, Laboratory of Lichenology E3LichLab, W. M. Bartla 19C/61, 30-389 Kraków, Poland; e-mail: grzzbll@wp.pl Maja Lisowska, Centre for Polar Studies, Faculty of Earth Sciences, University of Silesia, Będzińska 60, 41-200 Sosnowiec, Poland; e-mail: maja.lisowska@us.edu.pl

Katarzyna Pietrzykowska-Urban, Department of Botany, Institute of Environmental Biology, University of Wroctaw, Kanonia 6/8,50-328Wroctaw, Poland; e-mail: pietrzykowska.poczta@gmail.com

Anna Sadowska-Deś, LOEWE Biodiversity and Climate Research Centre (BiK-F), Senckenberg Gesellschaft für Naturforschung, Senckenberganlage 25, D-60325 Frankfurt am Main, Germany; Department of Biological Sciences, Goethe Universität Frankfurt, Max-von-Laue-Str. 9, D-60438 Frankfurt am Main, Germany; e-mail: anna-d-sadowska@o2.pl

Elżbieta Studzińska-Sroka, Department of Pharmacognosy, Poznan University of Medical Sciences, Święcickiego 4, 60-781 Poznań, Poland; e-mail: ela_studzinska@op.pl

Piotr T. Zaniewski, Department of Forest Botany, Faculty of Forestry, Warsaw University of Life Sciences - SGGW, Nowoursynowska 159,02-787 Warszawa,Poland; e-mail: piotr.zaniewski@wl.sggw.pl

Daria Zarabska-Bożejewicz, Institute for Agricultural and Forest Environment of Polish Academy of Science, Bukowska 19, 60-809 Poznań, Poland; e-mail: zardaria@wp.pl

\section{INTRODUCTION}

Magurski National Park (MNP) was founded in 1995 for the purpose of protecting the most important landscape and natural formations typical of the Beskid Niski Mts, which are part of the Western Carpathians (Kondracki 1989). The Beskid Niski Mts are low and intermediate-height mountains built of Carpathian flysch (Fig. 1). Altitude ranges mainly from 650 to $700 \mathrm{~m}$ a.s.l., reaching maximum of $847 \mathrm{~m}$ at the summit of Magura Wątkowska Mt. The park covers 19,439 ha of the Wisłoka River valley, including its upper reaches and origin. MNP is located in a pass in the Carpathians where two

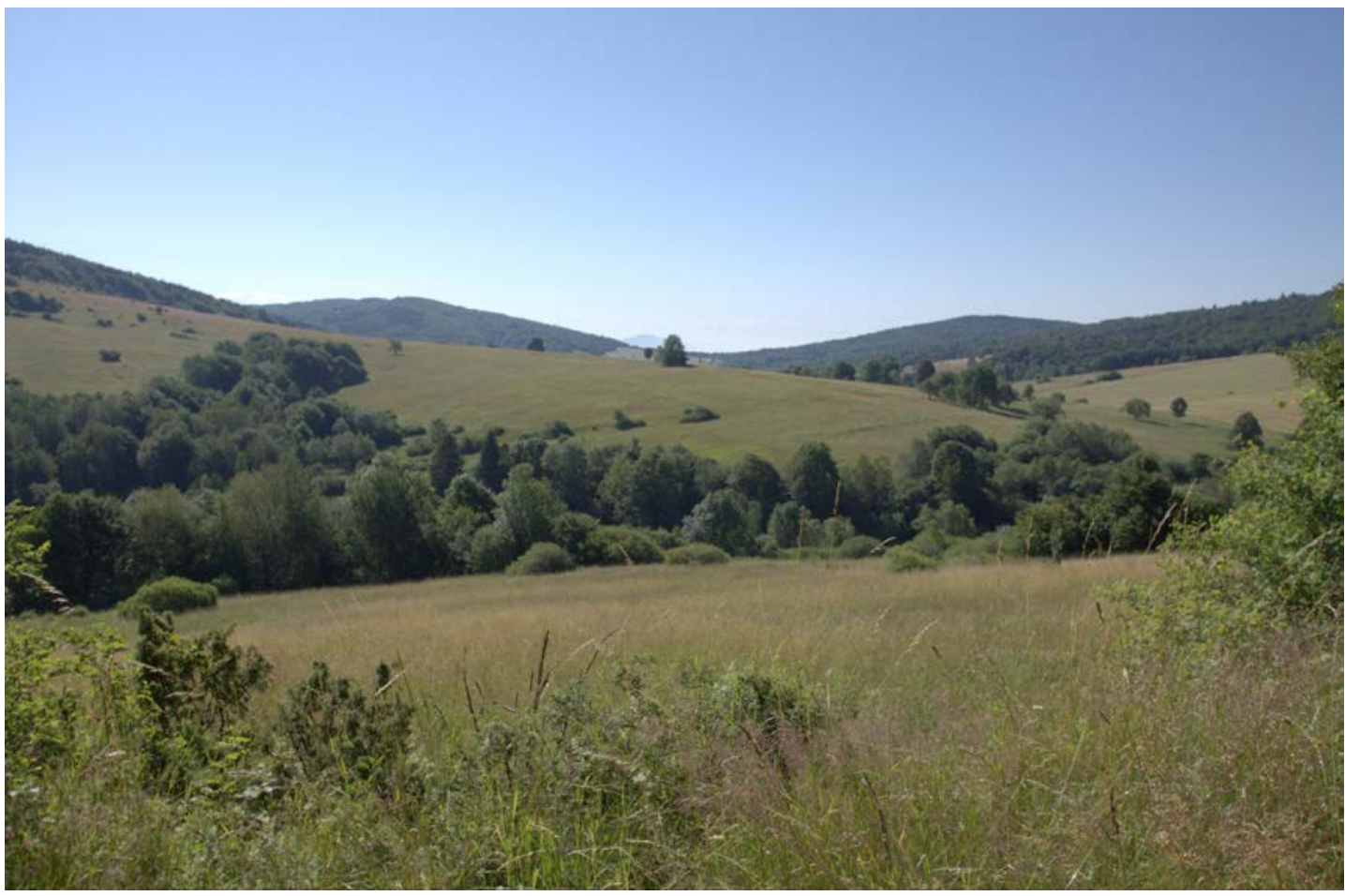

Fig. 1. Typical landscape of the Beskid Niski Mts - view of Ciechania village in Magurski National Park. Photo M. Węgrzyn. 


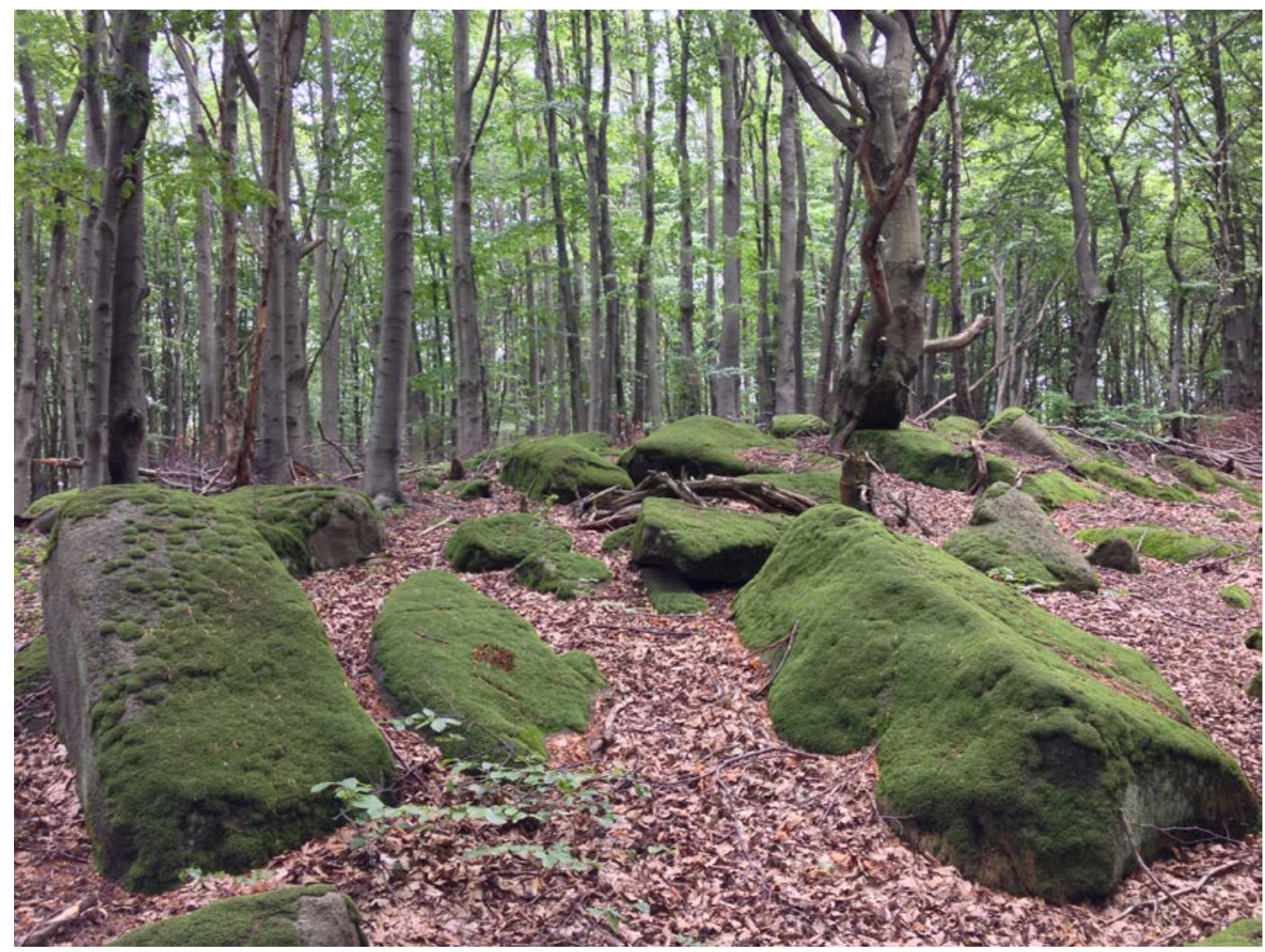

Fig. 2. Dentario glandulosae-Fagetum - dominant forest association in Magurski National Park. Photo M. Węgrzyn.

main ecological corridors intersect: north-south and east-west. The park is a typical woodland ( $90 \%$ wooded area) with relatively well-preserved vegetation. The most frequent forest community is Dentario glandulosae-Fagetum, which creates the characteristic landscape of the park (Fig. 2). Sycamore woods, rare in the Polish Carpathians, are represented by three associations: Sorbo-Aceretum, which occurs only on the peak rocks on Kamien Mt., Phyllitido-Aceretum, occurring on Magura Wątkowska Mt., Kamień Mt. and Suchania Mt., as well as Lunario-Aceretum developed in several patches. In the foothills there are mainly planted and managed stands dominated by pine, as well as multi-species riparian forests, and rarely hornbeam woods. Non-forest vegetation is represented by varied meadow and grassland communities, and also peat-bogs. Biocenoses in MNP having a natural species composition and high stability helped to justify the inclusion of area in the Natura 2000 network; 14 kinds of habitats given in the annex to the Habitat Directive were identified here. Detailed information on the importance of the park and its vegetation is found in a monograph of MNP (Górecki \& Zemanek 2009).

Prior to this work, Magurski National Park was lichenologically the least-known national park in the Polish Carpathians. More than 300 lichen species have been recorded (Bielczyk 2003 and literature cited therein) in the Beskid Niski area, but the majority were reported from outside the park (e.g., Motyka 1927; Olech 1974; Kukwa \& Czarnota 2006) or are only historical records (e.g., Sulma 1936; Polakowska 2002 based on T. Sulma's collection). In the 1970s, MNP was studied by lichenologists from Kraków (J. Nowak, 
M. Olech, J. Kiszka, R. Kozik) but their herbarium collections were only partially examined and published in articles or taxonomic monographs (e.g., Kukwa 2005, 2011; Czarnota 2007; Flakus \& Kukwa 2009; Krzewicka 2009, 2012; see also Bielczyk \& Kozik 2009).

Recent lichenological fieldwork in MNP was done during the $24^{\text {th }}$ Meeting of Polish Lichenologists in September 2009, the results of which are presented here in the form of an annotated checklist of lichens, lichenicolous fungi and saprotrophic fungi known from MNP (taking into account all published data). Also, the lichenological values of MNP are characterized, and an attempt was made to evaluate changes in the lichen biota.

\section{MATERIAL AND METHODS}

This study is based on material we collected during fieldwork on 10-11 September 2009 at 58 localities in Magurski National Park (Fig. 3 and list of collecting sites given below); the collecting sites are mapped in the ATPOL grid square system (Zając 1978), subdivided into $1 \times 1 \mathrm{~km}$ squares. The taxa recognized in the field were listed and samples of others were collected for identification in the laboratory by standard lichenological methods, including spot tests, UV reaction and TLC (Orange et al. 2010). Voucher material is housed in KRAP, with some duplicates in GPN, KRAM and UGDA.

The species list below is based on (1) original data collected during the 2009 fieldwork, (2) unpublished historical collections from UGDA (by T. Sulma) and

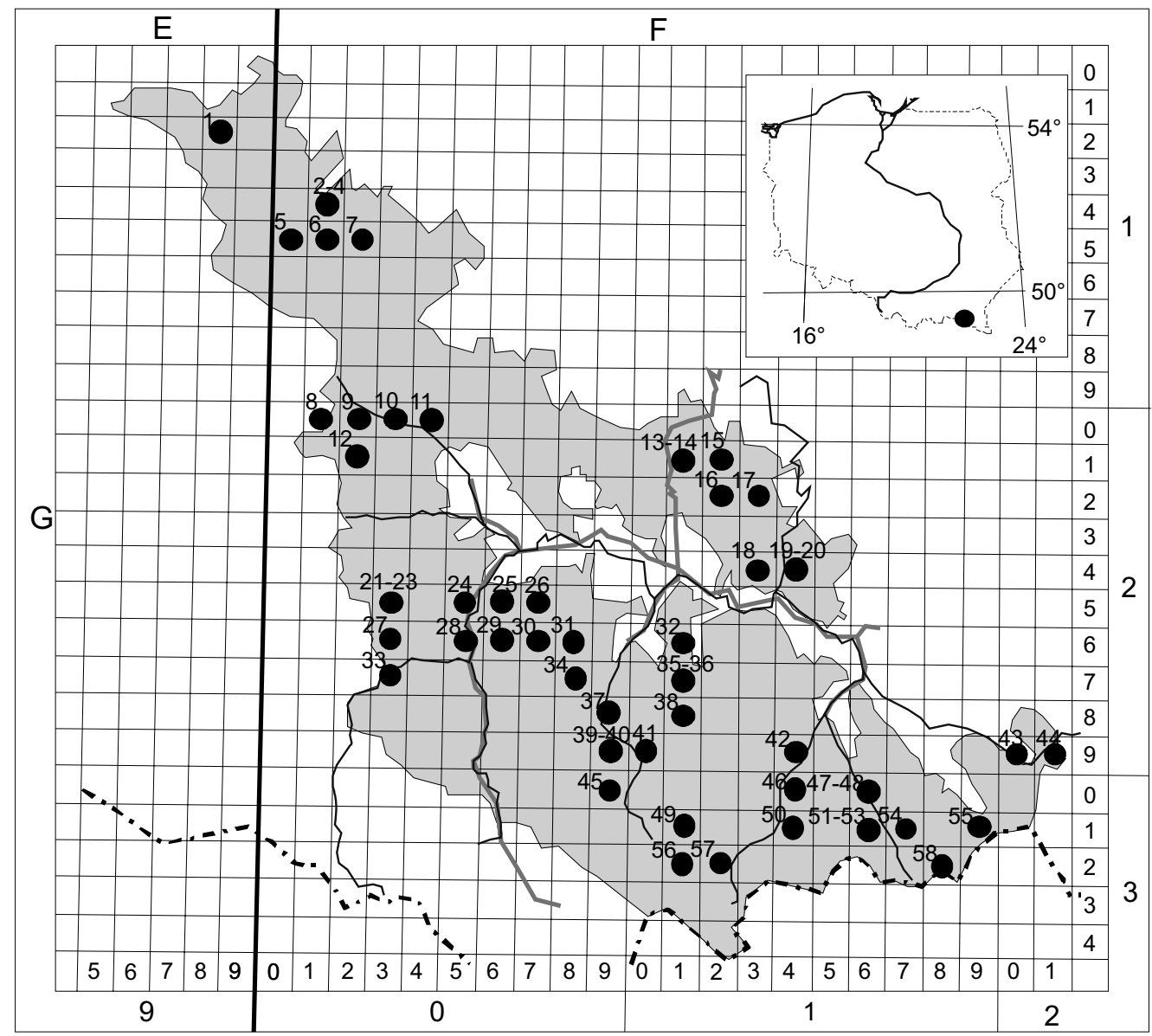

Fig. 3. Location of the collecting sites in Magurski National Park. 
KRAM (by J. Nowak), and (3) all earlier publications. Nomenclature of taxa follows the MycoBank Database (2015; http://www.mycobank.org) except for the genus Caloplaca, which is treated traditionally. For species whose nomenclature was changed recently, synonyms used in Bielczyk (2003) are provided.

\section{LIST OF COLLECTING SITES VISITED IN 2009}

1 - EG-1928: Bednarka stream, 49 $37^{\prime} 30^{\prime \prime} \mathrm{N}$, $21^{\circ} 19^{\prime} 52^{\prime \prime} \mathrm{E}$, alt. ca $440 \mathrm{~m}$, mixed forest with alder and ash.

2 - FG-1041: Diabli Kamień, 49³6'08.1"N, $21^{\circ} 22^{\prime} 05.3^{\prime \prime} \mathrm{E}$, alt. ca $500 \mathrm{~m}$, mixed forest with beech, fir, birch and pine, and moderately sunlit (peak parts) or heavily-shaded ( $\mathrm{N}$ exposure) sandstone rock.

3 - FG-1041: Diabli Kamień, by trail along Kłopotnica stream, $49^{\circ} 36^{\prime} 31.8^{\prime \prime} \mathrm{N}, 21^{\circ} 22^{\prime} 03.7^{\prime \prime} \mathrm{E}$, alt. ca $410 \mathrm{~m}$, mixed forest with ash and alder.

4 - FG-1041: Folusz, by road to Diabli Kamień, $49^{\circ} 36^{\prime} 38.5^{\prime \prime} \mathrm{N}, 21^{\circ} 22^{\prime} 16.0^{\prime \prime} \mathrm{E}$, alt. $c a 400$, sunlit roadside bank.

5 - FG-1050: Kornuty, crossing of forest road and yellow trail, $49^{\circ} 36^{\prime} 01.8^{\prime \prime} \mathrm{N}, 21^{\circ} 21^{\prime} 44^{\prime \prime} \mathrm{E}$, alt. $c a 450 \mathrm{~m}$, mixed forest with beech, fir, birch and larch, and roadside bank.

6 - FG-1051: Kosma Mt., SE slope, 49 $35^{\prime} 48.8^{\prime \prime} \mathrm{N}$, $21^{\circ} 22^{\prime} 40.5^{\prime \prime} \mathrm{E}$, alt. $c a 675$, mixed forest with high proportion of fir.

7 - FG-1052: Magurski waterfall, 49 $35^{\prime} 57.9^{\prime \prime} \mathrm{N}$, $21^{\circ} 23^{\prime} 09.2^{\prime \prime} \mathrm{E}$, alt. ca $520 \mathrm{~m}$, mixed forest with beech, fir, birch and pine, and steep sandstone rock above headstreams.

8 - FG-2001: Mareszka Mt., foot of NE slope, forest section no. $148 / 149,49^{\circ} 33^{\prime} 09^{\prime \prime} \mathrm{N}, 21^{\circ} 22^{\prime} 25^{\prime \prime} \mathrm{E}$, alt. ca $600 \mathrm{~m}$, ca 80-year-old Dentario glandulosaeFagetum.

9 - FG-2002: Mareszka Mt., NE slope, right tributary of Świerzówka stream, forest section no. $138,49^{\circ} 33^{\prime} 28^{\prime \prime} \mathrm{N}, 21^{\circ} 22^{\prime} 27^{\prime \prime} \mathrm{E}$, alt. ca $580 \mathrm{~m}$, young, ca 40-year-old beech-wood.

10 - FG-2003: Świerzowa Ruska, Świerzówka stream valley, $49^{\circ} 33^{\prime} 0.2^{\prime \prime} \mathrm{N}, 21^{\circ} 23^{\prime} 38^{\prime \prime} \mathrm{E}$, alt. ca $520 \mathrm{~m}$, abandoned orchard, ruderal brushwood.

11 - FG-2004: Świerzówka stream valley, forest section no. $135 / 121,49^{\circ} 32^{\prime} 54^{\prime \prime} \mathrm{N}, 2^{\circ} 24^{\prime} 23^{\prime \prime} \mathrm{E}$, alt. ca $495 \mathrm{~m}$, stream bed next to dirt road, marshy meadow, tall riverside brushwood.

12 - FG-2012: Mareszka Mt., E slope, forest section no. $146 / 147,49^{\circ} 32^{\prime} 28^{\prime \prime} \mathrm{N}, 21^{\circ} 22^{\prime} 53^{\prime \prime} \mathrm{E}$, alt. ca $700 \mathrm{~m}$, ca 120-140-year-old Dentario glandulosae-Fagetum.

13 - FG-2111: Kamień Mt., W slope, 49³2'17.4"N, $21^{\circ} 30^{\prime} 32.4^{\prime \prime} \mathrm{E}$, alt. ca $670 \mathrm{~m}$, Dentario glandulosae-Fagetum.

14 - FG-2111: Kamień Mt., summit part, $49^{\circ} 32^{\prime} 18.1^{\prime \prime} \mathrm{N}, 21^{\circ} 30^{\prime} 37.5^{\prime \prime} \mathrm{E}$, alt. $c a 700 \mathrm{~m}$, individual trees and boulders.

15 - FG-2112: Kamień Mt., NE slope, 49³2'15.2”N, $21^{\circ} 30^{\prime} 43.5^{\prime \prime}$ E, alt. ca $680 \mathrm{~m}$, Sorbo-Aceretum, single boulders.

16 - FG-2122: Kamień Mt., SE slope, 49³1'53.6"N, $21^{\circ} 31^{\prime} 03.7^{\prime \prime} \mathrm{E}$, alt. ca $680 \mathrm{~m}$, Dentario glandulosae-Fagetum.

17 - FG-2123: Kamień Mt., E slope, 4931'48”N, $21^{\circ} 31^{\prime} 47^{\prime \prime} \mathrm{E}$, alt. ca $480 \mathrm{~m}$, Ribeso nigri-Alnetum (Fig. 4).

18 - FG-2143: Kamień Mt., S ridge spur, E slope, $49^{\circ} 30^{\prime} 53.5^{\prime \prime} \mathrm{N}, 21^{\circ} 32^{\prime} 13.9^{\prime \prime} \mathrm{E}$, alt. ca $460 \mathrm{~m}$, PhyllitidoAceretum.

19 - FG-2144: Suchania Mt., W slope, 49 $30^{\prime} 29.6^{\prime \prime} \mathrm{N}$, $21^{\circ} 32^{\prime} 40.2^{\prime \prime} \mathrm{E}$, alt. ca $430 \mathrm{~m}$, Dentario glandulosaeFagetum.

20 - FG-2144: Suchania Mt., W slope, valley of stream flowing into Wilsznia river, $49^{\circ} 30^{\prime} 30.2^{\prime \prime} \mathrm{N}$, $21^{\circ} 32^{\prime} 29.6^{\prime \prime} \mathrm{E}$, alt. ca $360 \mathrm{~m}$, riverside alder forest, boulders in stream.

21 - FG-2053: Uherec Mt., S slope, forest section nos $291,292,49^{\circ} 30^{\prime} 24^{\prime \prime} \mathrm{N}, 21^{\circ} 22^{\prime} 33^{\prime \prime} \mathrm{E}$, alt. ca $500 \mathrm{~m}$, pine forest with some deciduous trees, young Dentario glandulosae-Fagetum.

22 - FG-2053: Uherec Mt., SW slope, forest section no. $289 / 290,49^{\circ} 30^{\prime} 25^{\prime \prime} \mathrm{N}, 21^{\circ} 22^{\prime} 34^{\prime \prime} \mathrm{E}$, alt. ca $600 \mathrm{~m}$, 80-100-year-old Dentario glandulosae-Fagetum, deep ravine.

23 - FG-2053: Uherec Mt., summit parts, forest section no. $167 / 291,49^{\circ} 30^{\prime} 36^{\prime \prime} \mathrm{N}, 21^{\circ} 23^{\prime} 33^{\prime \prime} \mathrm{E}$, alt. ca $680 \mathrm{~m}$, Dentario glandulosae-Fagetum.

24 - FG-2055: Wisłoka river valley, E slope of Uherec Mt., forest section no. $172 \mathrm{a}, 49^{\circ} 30^{\prime} 17.94^{\prime \prime} \mathrm{N}$, $21^{\circ} 25^{\prime} 00.59^{\prime \prime} \mathrm{E}$, alt. $400 \mathrm{~m}$, Dentario glandulosae-Fagetum.

25 - FG-2056: Cyrla Mt., NW slope, stream valley, forest section no. $150 \mathrm{c}, 49^{\circ} 30^{\prime} 14.09^{\prime \prime} \mathrm{N}, 21^{\circ} 25^{\prime} 58.7^{\prime \prime} \mathrm{E}$, alt. $500 \mathrm{~m}$, Dentario glandulosae-Fagetum.

26 - FG-2057: Świątkowa Mała, slopes above village, forest section no. $142 \mathrm{~b}, 49^{\circ} 30^{\prime} 17.81^{\prime \prime} \mathrm{N}$, $21^{\circ} 26^{\prime} 47.85^{\prime \prime} \mathrm{E}$, alt. $514 \mathrm{~m}$, fir-beech forest.

27 - FG-2063: surroundings of Nieznajowa, S slope of hill, forest section nos 293, 294, 49 $29^{\prime} 39^{\prime \prime} \mathrm{N}$, $21^{\circ} 23^{\prime} 32^{\prime \prime} \mathrm{E}$, alt. ca $500 \mathrm{~m}$, mixed forest, pasture.

28 - FG-2065: Wisłoka river valley, SE slope of Uherec Mt., forest section no. $173 \mathrm{a}, 49^{\circ} 29^{\prime} 52.00^{\prime \prime} \mathrm{N}$, $21^{\circ} 25^{\prime} 14.5^{\prime \prime} \mathrm{E}$, alt. $400 \mathrm{~m}$, Dentario glandulosae-Fagetum.

29 - FG-2066: Cyrla Mt., W slope, stream valley, 


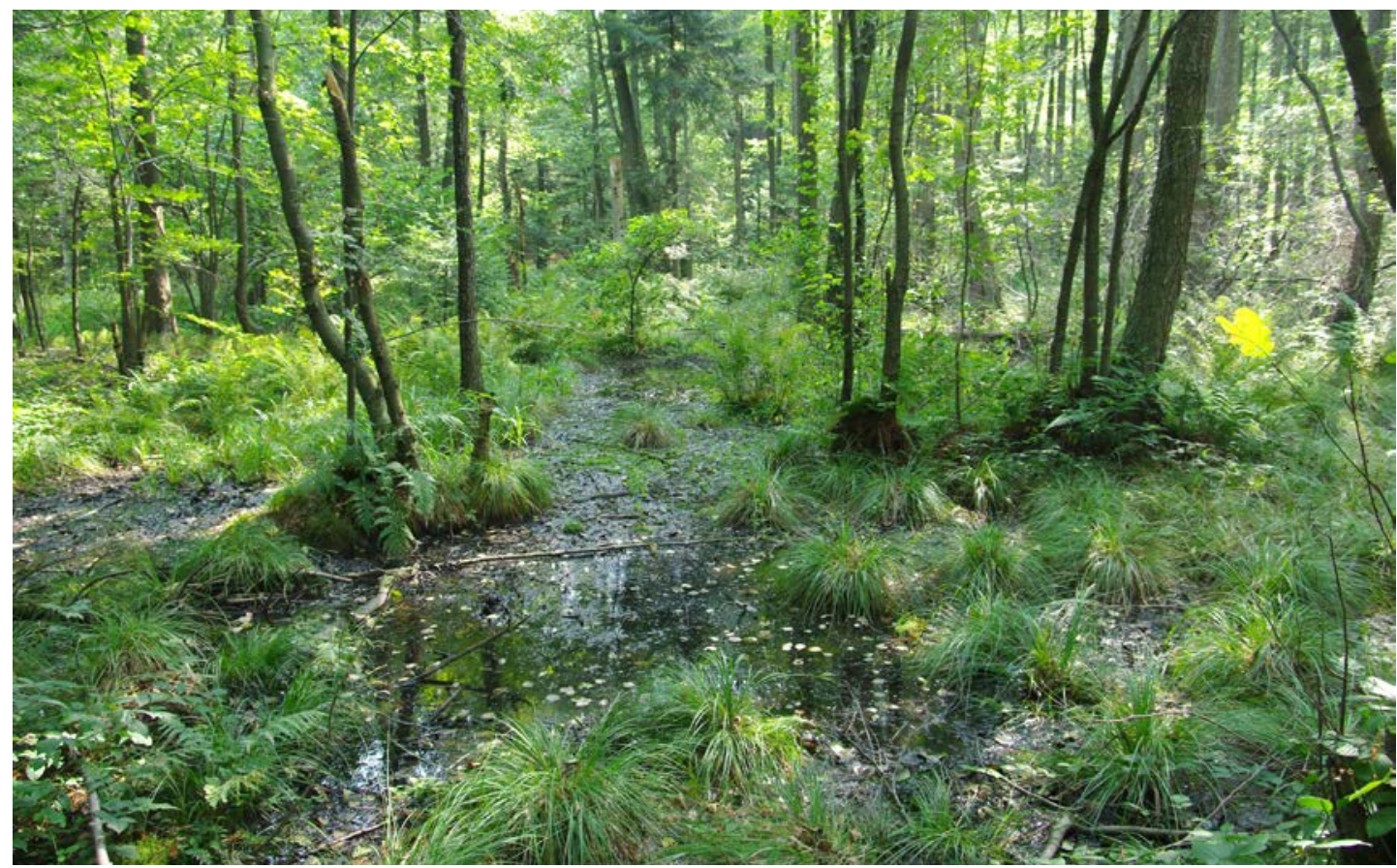

Fig. 4. Collecting site no. 17 with Ribeso nigri-Alnetum plant community - the site of Absconditella pauxilla Vězda \& Vivant. Photo R. Kościelniak.

forest section no. $152 \mathrm{a}, 49^{\circ} 29^{\prime} 41.28^{\prime \prime} \mathrm{N}, 21^{\circ} 25^{\prime} 54.27^{\prime \prime} \mathrm{E}$, alt. $550 \mathrm{~m}$, shady Dentario glandulosae-Fagetum.

30 - FG-2067: Cyrla Mt., summit parts, forest section no. $143 \mathrm{a}, 49^{\circ} 29^{\prime} 42.05^{\prime \prime} \mathrm{N}, 21^{\circ} 26^{\prime} 34.56^{\prime \prime} \mathrm{E}$, alt. $690 \mathrm{~m}$, fir forest.

31 - FG-2068: Krempna stream valley, Las Słodki, forest section no. $140 \mathrm{a}, 49^{\circ} 29^{\prime} 37.85^{\prime \prime} \mathrm{N}, 21^{\circ} 27^{\prime} 34.85^{\prime \prime} \mathrm{E}$, alt. $670 \mathrm{~m}$, shady Dentario glandulosae-Fagetum with scattered old sycamores.

32 - FG-2161: Huta Krempska, 49³9'49"N, $21^{\circ} 30^{\prime} 29^{\prime \prime} \mathrm{E}$, alt. $c a 450 \mathrm{~m}$, willows by stream.

33 - FG-2073: surroundings of Nieznajowa, Wisłoka river valley, forest section nos $157,158,49^{\circ} 29^{\prime} 22^{\prime \prime} \mathrm{N}$, $21^{\circ} 23^{\prime} 27^{\prime \prime} \mathrm{E}$, alt. $c a 435 \mathrm{~m}$, remains of sawmill, willowalder marshy meadow.

34 - FG-2078: Krempna stream valley, slopes of Słodkie Mt., forest section no. $146 \mathrm{a}, 49^{\circ} 29^{\prime} 01.72^{\prime \prime} \mathrm{N}$, $21^{\circ} 27^{\prime} 44.94^{\prime \prime} \mathrm{E}$, alt. $600 \mathrm{~m}$, shady Dentario glandulosaeFagetum with scattered old sycamores.

35 - FG-2171: Huta Krempska, ca $1 \mathrm{~km} \mathrm{SSW}$ of village, $49^{\circ} 28^{\prime} 58^{\prime \prime} \mathrm{N}, 21^{\circ} 30^{\prime} 19^{\prime \prime} \mathrm{E}$, alt. ca $500 \mathrm{~m}$, stream bank, forest, scattered trees.

36 - FG-2171: Huta Krempska, S of village, $49^{\circ} 29^{\prime} 20^{\prime \prime} \mathrm{N}, 21^{\circ} 30^{\prime} 34^{\prime \prime} \mathrm{E}$, alt. $440 \mathrm{~m}$, open area.

37 - FG-2089: Żydowskie, site of former center of destroyed village at foot of Kiczera Żydowska Mt., $49^{\circ} 28^{\prime} 34^{\prime \prime} \mathrm{N}, 21^{\circ} 28^{\prime} 15^{\prime \prime} \mathrm{E}$, alt. ca $450 \mathrm{~m}$, abandoned orchards; remains of buildings and graveyard.

38 - FG-2181: Las Huciska, ca $2.5 \mathrm{~km} \mathrm{SSW}$ of

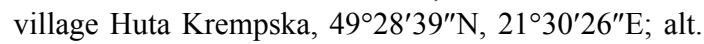
ca $600 \mathrm{~m}$, beech woods.

39 - FG-2099: Żydowskie, S foot of Wysokie Mt., $49^{\circ} 27^{\prime} 51^{\prime \prime} \mathrm{N}, 21^{\circ} 28^{\prime} 22^{\prime \prime} \mathrm{E}$, alt. ca $450 \mathrm{~m}$, abandoned apple orchards on edge of woods.

40 - FG-2099: Wysokie Mt., slope N, 49 $28^{\prime} 15.7^{\prime \prime} \mathrm{N}$, $21^{\circ} 28^{\prime} 10.5^{\prime \prime} \mathrm{E}$, alt. ca $500 \mathrm{~m}$, Dentario glandulosaeFagetum, boulders in stream.

41 - FG-2190: Żydowskie, site of former hamlet, by road to Ciechania (former state collective farm), $49^{\circ} 28^{\prime} 47^{\prime \prime} \mathrm{N}, 21^{\circ} 28^{\prime} 27^{\prime \prime} \mathrm{E}$, alt. ca $445 \mathrm{~m}$, boulders in stream, maple lane, remains of houses.

42 - FG-2194: Polany, ca $2 \mathrm{~km} \mathrm{SW}$ of village, Hucianka stream valley, $49^{\circ} 27^{\prime} 41^{\prime \prime} \mathrm{N}, 21^{\circ} 32^{\prime} 23^{\prime \prime} \mathrm{E}$, alt. ca $450 \mathrm{~m}$, open area.

43 - FG-2290: Wilsznia river, $49^{\circ} 27^{\prime} 46.4^{\prime \prime} \mathrm{N}$, $21^{\circ} 37^{\prime} 58.4^{\prime \prime} \mathrm{E}$, alt. $485 \mathrm{~m}$, remains of bridge.

44 - FG-2291: abandoned Wilsznia village, $49^{\circ} 27^{\prime} 42.2^{\prime \prime} \mathrm{N}, 21^{\circ} 38^{\prime} 04.6^{\prime \prime} \mathrm{E}$, alt. $490 \mathrm{~m}$, old orchard, plantings.

45 - FG-3009: slope of Wysokie Mt., 4927'36"N, 
$21^{\circ} 28^{\prime} 26^{\prime \prime} \mathrm{E}$, alt. $600 \mathrm{~m}$, initial grassland in gaps of plantations.

46 - FG-3104: Demcza, N of village Huta Polańska, $49^{\circ} 27^{\prime} 24^{\prime \prime} \mathrm{N}, 21^{\circ} 32^{\prime} 24^{\prime \prime} \mathrm{E}$, alt. ca $470 \mathrm{~m}$, forest, open area.

47 - FG-3106: Baranie stream valley, forest section no. $35 \mathrm{~b}, 49^{\circ} 27^{\prime} 20.8^{\prime \prime} \mathrm{N}, 21^{\circ} 34^{\prime} 02.9^{\prime \prime} \mathrm{E}$, alt. $480 \mathrm{~m}$, shady 70-90-year-old Dentario glandulosae-Fagetum.

48 - FG-3106: Baranie stream valley, forest section no. $36 \mathrm{~b}, 49^{\circ} 27^{\prime} 19^{\prime \prime} \mathrm{N}, 21^{\circ} 34^{\prime} 08.3^{\prime \prime} \mathrm{E}$, alt. $485 \mathrm{~m}$, roadside bank and edge of young fir-beech wood by forest road.

49 - FG-3111: Ciechania, $\mathrm{N}$ edge of destroyed village, below road to Żydowskie, $49^{\circ} 26^{\prime} 51^{\prime \prime} \mathrm{N}, 21^{\circ} 30^{\prime} 07^{\prime \prime} \mathrm{E}$, alt. $c a 590 \mathrm{~m}$, single trees in fields and by roads.

50 - FG-3114: Huta Polańska village, Hucianka stream valley, $49^{\circ} 27^{\prime} 01^{\prime \prime} \mathrm{N}, 21^{\circ} 32^{\prime} 22^{\prime \prime} \mathrm{E}$, alt. ca $470 \mathrm{~m}$, open area, church, churchyard, forest $\mathrm{E}$ of village.

51 - FG-3116: Baranie stream valley, forest section no. $25 \mathrm{a}, 49^{\circ} 27^{\prime} 09.8^{\prime \prime} \mathrm{N}, 21^{\circ} 04^{\prime} 26.9^{\prime \prime} \mathrm{E}$, alt. $500 \mathrm{~m}$, sunlit side of forest road, small outcrops.

52 - FG-3116: Baranie stream valley, forest section no. $25 \mathrm{a}, 49^{\circ} 27^{\prime} 07.8^{\prime \prime} \mathrm{N}, 21^{\circ} 34^{\prime} 32.7^{\prime \prime} \mathrm{E}$, alt. $550 \mathrm{~m}$, shady ca 90-year-old Dentario glandulosae-Fagetum.

53 - FG-3116: Baranie stream valley, forest section no. $35 \mathrm{a}, 49^{\circ} 27^{\prime} 26.6^{\prime \prime} \mathrm{N}, 21^{\circ} 34^{\prime} 05.4^{\prime \prime} \mathrm{E}$, alt. $470 \mathrm{~m}$, grove of young ash in streamside marshy meadow.

54 - FG-3117: Baranie stream valley, forest section no. $27 \mathrm{a}, 49^{\circ} 27^{\prime} 02.0^{\prime \prime} \mathrm{N}, 21^{\circ} 35^{\prime} 06.1^{\prime \prime} \mathrm{E}$, alt. $620 \mathrm{~m}$, shady Dentario glandulosae-Fagetum by stream.

55 - FG-3119: Olchowczyk stream valley, forest section no. $21 \mathrm{a}, 49^{\circ} 26^{\prime} 30.4^{\prime \prime} \mathrm{N}, 21^{\circ} 36^{\prime} 13.1^{\prime \prime} \mathrm{E}$, alt. $605 \mathrm{~m}$, shady Dentario glandulosae-Fagetum, beech tree-stand.

56 - FG-3121: Ciechania, center of destroyed village, $49^{\circ} 26^{\prime} 29^{\prime \prime} \mathrm{N}, 21^{\circ} 30^{\prime} 32^{\prime \prime} \mathrm{E}$, alt. ca $570 \mathrm{~m}$, remains of basements, abandoned orchards.

57 - FG-3122: Ciechania, surroundings of research station in Magurski National Park, SE of edge of destroyed village, $49^{\circ} 26^{\prime} 36^{\prime \prime} \mathrm{N}, 21^{\circ} 30^{\prime} 53^{\prime \prime} \mathrm{E}$, alt. $535 \mathrm{~m}$, abandoned orchards, meadows, wasteland.

58 - FG-3128: Baranie Mt., summit area, $49^{\circ} 26^{\prime} 13.4^{\prime \prime} \mathrm{N}, 21^{\circ} 35^{\prime} 51.2^{\prime \prime} \mathrm{E}$, alt. $754 \mathrm{~m}$, exposed, sunlit place.

\section{LIST OF SPECIES KNOWN FROM MNP}

As a result of fieldwork undertaken in 2009, 227 species of lichenized fungi, 12 of lichenicolous fungi and four of saprotrophic fungi traditionally included in lichenological lists, as well as one lichenicolous myxomycete species were recorded for the study area. The list below also contains 87 lichen species and six allied fungi previously reported from MNP, creating a complete list of 337 species currently known from this Carpathian national park.

For each species the following information is provided: habitat, number(s) of collecting site(s) and/or location of historical site(s), date and author of the collection, with reference to voucher specimen(s) and/or literature. For rare and taxonomically interesting species some comments are provided. Symbols: * - lichenicolous fungus, ${ }^{+}$- saprotrophic fungus, ${ }^{\#}$ - lichenicolous myxomycete, (!) - species new for the Beskid Niski Mts. Species recorded during the current study are bolded.

\section{*Abrothallus bertianus De Not.}

On thallus of Melanelixia glabratula growing on apple tree. Collecting site: 37 . (!)

Absconditella delutula (Nyl.) Coppins \& Kilias On shaded sandstone pebble. Collecting site: 53. (!)

\section{Absconditella lignicola Vězda \& Pišut}

On decaying tree stump and and wood of Abies alba log. Collecting sites: $8,30,54$. (!)

\section{Absconditella pauxilla Vězda \& Vivant}

On decaying tree stump. Collecting site: 17. (!)

Note. An inconspicuous, ephemeral species only recently recorded in Poland, known from Gdańsk Pomerania (Kukwa \& Zduńczyk 2011; Kukwa et al. 2013) and one locality in the Tatra Mts (Czarnota 2012). It usually grows on decaying wood of stumps and logs. Unlike other representatives of the genus, it forms narrow, needle-shaped ascospores.

Acarospora fuscata (Ach.) Th. Fr.

On sandstone and concrete. Collecting sites: 2, 41, 50. Historical data: Diabli Kamień Mt. (FG-1041), 1936, leg. T. Sulma (UGDA; Polakowska 2002); Rostajne (FG-2075), Krempna (FG-2151), Ciechania (FG-3121), 1979, leg. J. Nowak (KRAM; Bielczyk \& Kozik 2009).

Acarospora glaucocarpa (Wahlenb. in Ach.) Körb. On limestone wall; Polany (FG-2175), 1976, leg. J. Nowak (KRAM; Leśniański 2002). 
Acarospora moenium (Vain.) Räsänen

Aspicilia moenium (Vain.) G. Thor \& Timdal

On concrete. Collecting sites: 33,41 . (!)

Acarospora umbilicata Bagl.

On wall of old stone roadside shrine; Nieznajowa (FG2073), 1979, leg. J. Nowak (KRAM).

Acrocordia gemmata (Ach.) A. Massal.

On bark of beech, apple tree and sycamore. Collecting sites: 34, 54 .

Historical DATA: Folusz - stream valley (FG-1041), 1936, leg. T. Sulma (UGDA; Polakowska 2002); Żydowskie (FG-2180), 1979, leg. J. Nowak (KRAM).

\section{Agonimia repleta Czarnota \& Coppins}

On bark at base of beech trees and mossy boulder in forest. Collecting sites: 12, 52, 54. (!)

Note. An inconspicuous microlichen, described from specimens from the Gorce Mts (Czarnota \& Coppins 2000), nowadays frequently found in the Carpathians at the base and on roots of beech (Czarnota unpubl.).

\section{Alyxoria varia (Pers.) Ertz \& Tehler}

Opegrapha varia Pers.

On bark of beech, sycamore and apple tree. Collecting sites: 10, 26, 30, 34, 44 .

\section{Anaptychia ciliaris (L.) Körb.}

On bark of roadside willow; Folusz - stream valley (FG1041), 1955, leg. T. Sulma (UGDA; Polakowska 2002); Nieznajowa (FG-2073), 1974, leg. J. Nowak (KRAM; Bielczyk \& Kozik 2009).

\section{Anisomeridium polypori (M. B. Ellis \& Everh.)} M. E. Barr

On bark of deciduous trees, mainly in forests, less frequently in open areas. Collecting sites: $33,35,38,53$, 54. (!)

Note. In the Polish part of the Carpathians the species was found in the Gorce Mts (Czarnota 2010), Babia Góra Massif (Czarnota \& Węgrzyn 2012), the Pogórze Wiśnickie foothills (Śliwa 2010) and the Bieszczady Mts (Kościelniak 2013); recently it has spread into many regions of Europe; it can be locally common but most frequently it occurs in an anamorphic form with pycnidia characterized by its conical, elongated ostioles.

Arthonia atra (Pers.) A. Schneid.

Opegrapha atra Pers.

On bark of apple tree in abandoned orchard. Collecting site: 44. (!)

Arthonia radiata (Pers.) Ach.

On bark of deciduous trees, mainly beech. Collecting sites: 5, 24, 34, 46, 54 .

\section{Arthonia spadicea Leight.}

On bark of deciduous trees in forests. Collecting sites: $1,9,35,38,52,53$.

HISTORICAL DATA: Nieznajowa (FG-2064), Rostajne (FG2074), 1979, leg. J. Nowak (KRAM; Bielczyk 2003).

*Arthorhaphis aeruginosa R. Sant. \& Tønsberg On Cladonia sp. growing on soil; Diabli Kamień Mt. (FG-1041), 1955, leg. T. Sulma (UGDA; Polakowska 2002).

Arthothelium ruanum (A. Masasl.) Körb.

Arthonia ruana A. Massal.

On bark of deciduous trees in shaded places in forests. Collecting sites: 1, 15, 18, 19, 35, 40.

Historical DATA: Nieznajowa (FG-2064), Krempna (FG-2069), Rostajne (FG-2074), Skarpoty (FG-2079), 1979, leg. J. Nowak (KRAM; Nowak 1983).

Aspicilia cf. laevata (Ach.) Arnold

On boulder; Diabli Kamień Mt. (FG-1041), 1955, leg. T. Sulma (UGDA; Polakowska 2002).

"Athelia arachnoidea (Berk.) Jülich

On Lecanora conizaeoides and Scoliciosporum chlorococcum growing on fir. Collecting sites: $2,7,34,35$, 53. (!)

\section{Bacidia pycnidiata Czarnota \& Coppins}

On decaying bark of $\log$ and wood of beech stump. Collecting sites: 46, 53. (!)

NoTE. Usually a epibryophytic species, distinctive for its sorediate thallus and numerous pale to brown, globose external pycnidia with long, ostiolar necks. Originally it was reported from the 
Czech Republic (E Sudetes) and Poland (Gorce Mts and Pogórze Strzyżowskie foothills) (Czarnota \& Coppins 2006); currently it is known from additional sites in both countries (Lubek 2009, 2012; Vondrák et al. 2010b; Czarnota \& Hernik 2014). It has also been found in Estonia, Belgium, Finland, Lithuania, Ukraine, the North Caucasus and the European part of Russia (Urbanavichene \& Urbanavichus 2014).

\section{Bacidia rubella (Hoffm.) A. Massal.}

On bark of sycamore, ash and apple tree. Collecting sites: $8,10,15,34,38,54$.

\section{Bacidia subincompta (Nyl.) Arnold}

On bark of apple tree, beech, willow, ash and sycamore. Collecting sites: $10,12,15,19,35,38,47,54$. (!)

Bacidia viridescens (A. Massal). Norman

On concrete wall. Collecting site: 33 . (!)

Bacidina adastra (Sparrius \& Aptroot) M. Hauck \& V. Wirth

On bark of apple tree and willow. Collecting sites: 5, 35. (!)

Bacidina cf. brandii (Coppins \& van den Boom) M. Hauck \& V. Wirth

On blown-down tree. Collecting site: 19. (!)

Note. So far this species has been reported from only one locality in NE Poland (Kubiak $\&$ Sparrius 2004), but revision of the source material revealed that the specimen represents a specific morphotype of Bacidina sulphurella (Samp.) M. Hauck \& V. Wirth (Czarnota unpubl.). The specimen found in Magurski National Park resembles a pale form of $B$. brandii but its thallus is composed of tiny yet distinct goniocysts and its exciple of branched hyphae. According to the original description (Coppins \& van den Boom 2002), B. brandii is characterized by its crustose thallus built of flat, confluent areoles and a paraplectenchymatic exciple with wide cells (6-10 $\mu \mathrm{m})$. The presence of Arnoldiana-brown pigment in the hypothecium suggests that the specimen belongs to the group B. arnoldiana, but this requires further research.

\section{Bacidina egenula (Nyl.) Vězda}

On sandstone structure of old bridge. Collecting site: 43. (!)

Note. In Poland the species is considered critically endangered (Cieśliński et al. 2006) but its threat category seems to be due to insufficient data. Several records of this species in the Polish Western Carpathians (wet microhabitats on manmade constructions) show that at least in this part of the country it is locally more frequent (Czarnota unpubl.).

\section{Bacidina inundata (Fr.) Vězda}

Bacidia inundata (Fr.) Körb.

On sandstone sprinkled with water. Collecting sites: $1,7,40$.

Bacidina cf. neosquamulosa (Aptroot \& van Herk) S. Ekman

On bark of ash and willow. Collecting sites: 33, 54. (!)

Note. The examined specimens with fruiting bodies possessed anatomical characteristics resembling $B$. neosquamulosa but differing in the structure of the thallus, which is indeterminate to granular, unlike the coralloid one which characterizes B. neosquamulosa s.str. Similar specimens have been recorded in different regions of Poland and elsewhere (Czarnota unpubl.). The possible taxonomic differentiation of the materials requires molecular proofs.

\section{Bacidina phacodes (Körb.) Vězda}

On bark of elm. Collecting site: 30 .

Bacidina saxenii (Erichsen) M. Hauck \& V. Wirth On sandstone in forest. Collecting site: 48.

Note. An inconspicuous, ephemeral species, often inhabiting small stones in ruderal localities, reported from several localities in Poland, including the buffer zone of Magurski National Park, near the village of Kotań (Czarnota \& Coppins 2007).

\section{Bacidina sulphurella (Samp.) M. Hauck \& V. Wirth} On bark and epiphytic bryophytes of apple tree, willow, alder and ash. Collecting sites: 1, 6, 33, 46, 50, 54. (!) 
Baeomyces rufus (Huds.) Rebent.

On soil, wood, roots and sandstone. Collecting sites: 2 , $13,14,15,17,19,29,31,34,45,47,48$.

Historical Data: Folusz - stream valley (FG-1041), Diabli Kamień Mt. (FG-1041), 1954, 1957, leg. T. Sulma (UGDA; Polakowska 2002).

\section{Biatora chrysantha (Zahlbr.) Printzen}

On epiphytic bryophytes on beech and bark of willow and cherry tree. Collecting sites: 1, 16, 26, 28, 29. (!)

Biatora efflorescens (Hedl.) Räsänen

On bark of sycamore. Collecting site: 34 .

\section{Biatora epixanthoides (Nyl.) Diederich}

Mycobilimbia epixanthoides (Nyl.) Hafellner \& Türk

On epiphytic bryophytes of elm, beech, willow and cherry tree. Collecting sites: $1,15,33,51$. (!)

Biatora globulosa (Flörke) Fr.

Bacidia globulosa (Flörke) Hafellner \& V. Wirth.

On bark of willow and apple tree. Collecting site: 44 .

Bilimbia sabuletorum (Schreb.) Arnold

Myxobilimbia sabuletorum (Schreb.) Hafellner

On bryophytes growing on concrete. Collecting sites: $33,43,50$.

Botryolepraria lesdainii (Hue) A. Canals, Hern.Mar., Gómez-Bolea \& Llimona

Lepraria lesdainii (Hue) R. C. Harris

On sandstone rock. Collecting site: 7. (!)

Bryoria capillaris (Ach.) Brodo \& D. Hawksw.

Habitat not given; Folusz - stream valley (FG-1041), 1936, leg. T. Sulma (UGDA; Polakowska 2002).

Buellia griseovirens (Turner \& Borrer ex Sm.) Almb.

On bark of deciduous trees and fir, on wood in one locality. Collecting sites: 10, 11, 16, 17, 19, 27, 29, 31, 33, 42, 44, 50, 54, 58.

Historical Data: Diabli Kamień Mt. (FG-1041), 1954, leg. T. Sulma (UGDA; Polakowska 2002); Krempna (FG-2069), 1979, leg. J. Nowak (KRAM; Nowak 1998).

Buellia punctata (Hoffm.) A. Massal. Amandinea punctata (Hoffm.) Coppins \& Scheid.
On bark of deciduous trees and wood. Collecting sites: 1, 10, 11, 27, 28, 29, 31, 33, 34, 39, 41, 42, 50, 54, 58. Historical DATA: Folusz - stream valley (FG-1041), 1957, leg. T. Sulma (UGDA; Polakowska 2002); Krempna (FG-2069), Rostajne (FG-2074), 1979, leg. J. Nowak (KRAM; Nowak 1998; Bielczyk \& Kozik 2009).

\section{*Burgoa angulosa Diederich, Lawrey \& Etayo}

On decaying lichens and bark. Collecting site: 42. (!)

Note. A facultative lichenicolous or muscicolous species, on rocks and bark. It is characterized by its whitish bulbils of irregular shape and often angular surface, elongate internal hyphae, and no specialized external cells. The species has recently been described and reported from Belgium, France, Spain, Luxemburg, Great Britain and Hungary (Diederich \& Lawrey 2007). Here it is recorded for the first time for Poland and the whole Carpathian range.

Caeruleum heppii (Nägeli ex Körb.) K. Knudsen \& L. Arkadia

Acarospora heppii (Nägeli) Nägeli

On stones on roadside bank. Collecting site: 33 .

\section{Calicium viride Pers.}

On decayed fir. Collecting site: 26.

Caloplaca cerina (Ehrh. ex Hedw.) Th. Fr. s.l.

On old wooden roof shingles; Nieznajowa (FG-2073), 1979, leg. J. Nowak (KRAM).

Note. The species is heterogenic (Šoun et al. 2011).

\section{Caloplaca cerinella (Nyl.) Flagey}

On bark of alder; Folusz - stream valley (FG-1041), 1957, leg. T. Sulma (UGDA; Polakowska 2002).

Caloplaca citrina (Hoffm.) Th. Fr.

On sandstone in old bridge structure and on concrete wall. Collecting sites: $33,41,43$.

\section{Caloplaca crenulatella (Nyl.) H. Olivier}

On concrete. Collecting site: 41. (!)

Historical Data: Świerzowa Ruska (FG-2003), 1979, leg. J. Nowak (KRAM). 
Caloplaca decipiens (Arnold) Blomb. \& Forssell

On concrete. Collecting site: 41 . (!)

\section{Caloplaca flavocitrina (Nyl.) H. Olivier}

On mortar and concrete. Collecting sites: 33, 46, 50. (!)

Caloplaca holocarpa (Hoffm.) A. E. Wade s.l.

On mortar and concrete. Collecting sites: 15, 33, 46, $50,56,57$.

Caloplaca oasis (A. Massal.) Szatala

On concrete. Collecting site: 41. (!)

Note. This species is separated from C. holocarpa (Hoffm.) A. E. Wade s.str. by its more prominent, yellow thallus, and apothecia tending to be more deeply orange, crowded, rather uniform in size, with a thinner proper margin that becomes indistinguishable from the apothecial discs; some anatomical differences are given by Arup (2009). The species perhaps is frequent but overlooked in the Carpathians (Wilk 2012).

\section{Caloplaca phlogina (Ach.) Flagey}

On bark of poplar. Collecting site: 46. (!)

Note. This is a corticolous representative of the $C$. citrina group. Substrate ecology seems to be the best way to separate the species from $C$. citrina itself. $C$. phlogina may be confused with $C$. $f l a-$ vocitrina, which may occur on the same kind of phorophyte (bark with high $\mathrm{pH}$ ). The latter species differs from $C$. phlogina, which is entirely sorediate, in having an areolate thallus only partly dissolved into soredia (Arup 2006). In Poland it is known from the Bory Tucholskie forest (Kukwa et al. 2013).

Caloplaca pusilla (A. Massal.) Zahlbr.

On concrete. Collecting sites: 41, 46. (!)

Note. It is a common representative of Caloplaca, often confused with $C$. saxicola. C. pusilla differs from the latter by having a distinctly placodioid thallus with long lobes tightly attached to the substrate, and according to Wilk (2012) it is widespread in the Polish Carpathians.
Candelaria concolor (Dick.) Stein

On bark of apple tree. Collecting site: 45.

Historical DATA: on bark of willow; Folusz - stream valley (FG-1041), 1957, leg. T. Sulma (UGDA; Polakowska 2002); Wyszowatka towards Rostajne (FG2095), 1979, leg. J. Nowak (KRAM).

Candelariella aurella (Hoffm.) Zahlbr.

On concrete and mortar. Collecting sites: 15, 33, 35, $41,42,46,50$.

Historical DATA: Folusz - stream valley (FG-1041), s.d., leg. T. Sulma (UGDA; Polakowska 2002).

Candelariella coralliza (Nyl.) H. Magn.

On sandstone rocks; Nieznajowa (FG-2073), 1979, leg. J. Nowak (KRAM; Bielczyk 2003; Bielczyk \& Kozik 2009).

Candelariella efflorescens R. C. Harris \& W. R. Buck

On bark of deciduous trees. Collecting sites: 1, 10, 21, 22, 33, 35, 36, 39, 41, 42, 44.

HistoricAl DATA: Folusz - stream valley (FG-1041), 1957, leg. T. Sulma (UGDA; Polakowska 2002 as C. reflexa auct.).

NoTE. It is a sorediate species with polysporous asci, previously misidentified in Poland as C. reflexa (Nyl.) Lettau (Kubiak \& Westberg 2011). The species was reported by the latter authors from northern and central parts of the country, and by Śliwa and Kukwa (2012) from the Tatra Mts.

Candelariella vitellina (Hoffm.) Müll. Arg.

On sandstone rock, concrete wall and granite post. Collecting sites: 33, 50, 56.

Historical DATA: Kornuty Reserve (EG-1969) (Sulma 1936).

Candelariella xanthostigma (Pers. ex Ach.) Lettau

On bark of deciduous trees. Collecting sites: 10, 20, 28, 33, 37, 39, 41, 44, 46, 50, 56, 58.

Historical Data: Folusz - stream valley (FG-1041), 1957, leg. T. Sulma (UGDA; Polakowska 2002).

\section{${ }^{*}$ Carbonea supersparsa (Nyl.) Hertel}

On Lecanora polytropa growing on rock; Diabli Kamień Mt. (FG-1041), 1936, leg. T. Sulma (UGDA; Kukwa 2005). 


\section{Cetraria chlorophylla (Willd.) Vainio}

On bark of trees; Folusz - stream valley (FG-1041), Diabli Kamień Mt. (FG-1041), 1936, leg. T. Sulma (UGDA; Polakowska 2002).

Cetraria islandica (L.) Ach.

On rock waste; Kornuty Reserve (EG-1969) (Sulma 1936).

Chaenotheca brunneola (Ach.) Müll. Arg.

On standing decorticated wood in forests. Collecting sites: $8,15,40 .(!)$

Chaenotheca chrysocephala (Ach.) Th. Fr.

On bark of fir and willow, on wood. Collecting sites: $31,34,44$.

Historical Data: Świerzowa Ruska (FG-2003), Skarpoty (FG-2079), Krempna (FG-2151), 1979, leg. J. Nowak (KRAM).

Chaenotheca ferruginea (Turner ex Sm.) Mig.

On bark of fir, pine, alder and pear tree, and wood in forests. Collecting sites: 1, 2, 8, 15, 17, 16, 22, 27, 34, 40.

Historical Data: Żydowskie (FG-2180), 1979, leg. J. Nowak (KRAM; Bielczyk 2003; Bielczyk \& Kozik 2009).

Chaenotheca furfuracea (L.) Tibell

On bark of elm. Collecting site: 34 .

Chaenotheca phaeocephala (Turner) Th. Fr.

On bark of fir and sycamore, on wood. Collecting sites: $13,15,16,34 .(!)$

Chaenotheca stemonea (Ach.) Müll. Arg.

On bark of old fir and alder, on wood. Collecting sites: 17,33 .

Historical data: Las Spełzły (FG-2062), 1979, leg. J. Nowak (KRAM; Bielczyk 2003).

Chaenotheca trichialis (Ach.) Th. Fr.

On wood, bark of beech and fir. Collecting sites: 6, 40 .

Historical DATA: Folusz - stream valley (FG-1041), 1957, leg. T. Sulma (UGDA; Polakowska 2002).

\section{Chaenotheca xyloxena Nádv.}

On wood of fir. Collecting sites: 8, 7, 23, 31, 34, 40, 53,54 .
"Chaenothecopsis pusilla (Ach.) A. F. W. Schmidt

On wood of beech and thallus of Chaenotheca xyloxena. Collecting sites: $8,23,40$. (!)

Chrysothrix candelaris (L.) J. R. Laundon

On bark of beech and fir; Folusz - stream valley (FG1041), 1957, leg. T. Sulma (UGDA; Polakowska 2002).

Cladonia arbuscula (Wallr.) Flot. subsp. beringiana Ahti

C. arbuscula subsp. squarrosa (Wallr.) Ruoss

On boulder; Diabli Kamień Mt. (FG-1041), 1957, leg. T. Sulma (UGDA; Polakowska 2002).

Cladonia arbuscula subsp. mitis (Sandst.) Ruoss On soil; Folusz - stream valley (FG-1041), 1936, leg. T. Sulma (UGDA; Polakowska 2002).

Cladonia borealis S. Stenroos

On soil; Diabli Kamień Mt. (FG-1041), 1957, leg. T. Sulma (UGDA; Polakowska 2002).

Cladonia caespiticia (Pers.) Flörke

At base of birch stump and on clay soil. Collecting sites: $1,13$.

Historical data: Diabli Kamień Mt. (FG-1041), Kornuty Reserve (EG-1969), 1955, leg. T. Sulma (UGDA; Sulma 1936; Polakowska 2002); Ostryszne near Krempna (FG-2153), 1979, leg. J. Nowak (KRAM; Nowak 1995).

Cladonia cariosa (Ach.) Spreng.

On soil. Collecting site: 36 . (!)

Cladonia cenotea (Ach.) Schaer.

On bryophytes at base of beech and on boulder. Collecting site: 19.

Historical Data: Diabli Kamień Mt. (FG-1041), 1957, leg. T. Sulma (UGDA; Polakowska 2002).

\section{Cladonia chlorophaea (Sommerf.) Speng.}

On soil, bark of deciduous trees, boulder and wood. Collecting sites: $9,10,17,22,24,25,26,29,31,33$, $34,44,45$.

Historical Data: Folusz - stream valley (FG-1041), Diabli Kamień Mt. (FG-1041), 1954-57, leg. T. Sulma (UGDA; Polakowska 2002); Nieznajowa (FG-2064), 1979, leg. J. Nowak (KRAM). 
Cladonia coccifera (L.) Willd. s.l.

On rock waste; Folusz - stream valley (FG-1041), Diabli Kamień Mt. (FG-1041), Kornuty Reserve (EG-1969), 1954-62, leg. T. Sulma (UGDA; Sulma 1936; Polakowska 2002).

\section{Cladonia coniocraea (Flörke) Spreng.}

incl. Cladonia ochrochlora Flörke

On bark of trees, wood, soil and boulders. Collecting sites: $1,3,5,6,8,9,10,14,15,16,17,18,19,20,24$, 26, 29, 30, 31, 34, 35, 38, 39, 48, 44, 50, 51, 52, 56.

HistORICAL DATA: Folusz - stream valley (FG-1041), Diabli Kamień Mt. (FG-1041), 1954-62, leg. T. Sulma (UGDA; Polakowska 2002); Nieznajowa (FG-2064), Krempna (FG-2069), 1979, leg. J. Nowak (KRAM; Bielczyk 2003).

Cladonia cornuta (L.) Hoffm.

On soil and boulder. Collecting sites: 15, 16.

Historical DATA: Folusz - stream valley (FG-1041), Diabli Kamień Mt. (FG-1041), 1955-62, leg. T. Sulma (UGDA; Polakowska 2002).

Cladonia crispata (Ach.) Flot.

On soil; Folusz - stream valley (FG-1041), Diabli Kamień Mt. (FG-1041), 1955, leg. T. Sulma (UGDA; Polakowska 2002).

Cladonia deformis (L.) Hoffm.

On soil; Diabli Kamień Mt. (FG-1041), 1955, leg. T. Sulma (UGDA; Polakowska 2002).

\section{Cladonia digitata (L.) Hoffm.}

On bark of trees, wood, soil, and bryophytes on rocks. Collecting sites: 2, 8, 14, 15, 16, 17 .

Historical Data: Folusz - stream valley (FG-1041), Diabli Kamień Mt. (FG-1041), 1954-62, leg. T. Sulma (UGDA; Polakowska 2002).

\section{Cladonia fimbriata (L.) Fr.}

On bark of trees, soil, wood, and bryophytes on rocks. Collecting sites: $2,5,9,10,14,15,16,17,19,20,24$, 25, 26, 28, 31, 34, 35, 38, 42, 43, 44, 46, 48, 50, 51.

Historical DATA: Folusz - stream valley (FG-1041), Diabli Kamień Mt. (FG-1041), 1954-57, leg. T. Sulma (UGDA; Polakowska 2002); Hałbów (FG-2100), 1979, leg. J. Nowak (KRAM).

\section{Cladonia floerkeana (Fr.) Flörke}

C. macilenta subsp. floerkeana (Fr.) V. Wirth
On bark of apple tree and boulder. Collecting site: 10 . Historical DATA: Folusz - stream valley (FG-1041), Diabli Kamień Mt. (FG-1041), 1954-62, leg. T. Sulma (UGDA; Polakowska 2002).

Cladonia furcata (Huds.) Schrad.

On soil and boulder. Collecting sites: 33, 41.

Historical Data: Folusz - stream valley (FG-1041), Diabli Kamień Mt. (FG-1041), 1954-62, leg. T. Sulma (UGDA; Polakowska 2002).

\section{Cladonia glauca Flörke}

On bark of sycamore. Collecting site: 15 .

\section{Cladonia gracilis (L.) Willd.}

On soil in rock crevices; Folusz - stream valley (FG1041), Diabli Kamień Mt. (FG-1041), Kornuty Reserve (EG-1969), 1954-62, leg. T. Sulma (UGDA; Sulma 1936; Polakowska 2002).

Cladonia humilis (With.) J. R. Laundon

On epiphytic bryophytes of beech. Collecting site: 12. (!)

\section{Cladonia macilenta Hoffm.}

On bark of deciduous trees, wood, soil, and bryophytes on rock. Collecting sites: $1,2,5,6,7,10,14,15,18$, 22, 34, 38 .

Historical DATA: Folusz - stream valley (FG-1041), Diabli Kamień Mt. (FG-1041), 1936, 1954-57, leg. T. Sulma (UGDA; Polakowska 2002).

Cladonia macroceras (Delise) Hav.

On boulder; Folusz - stream valley (FG-1041), 1962, leg. T. Sulma (UGDA; Polakowska 2002).

\section{Cladonia macrophyllodes Nyl.}

On soil; Folusz - stream valley (FG-1041), 1957, leg. T. Sulma (UGDA; Polakowska 2002).

\section{Cladonia merochlorophaea Asahina}

On rock, stones and epilithic mosses; Diabli Kamień Mt. (FG-1041), 1954-56, leg. T. Sulma (UGDA; Polakowska 2002).

Cladonia monomorpha Aptroot, Sipman \& van Herk

On boulder; Folusz - stream valley (FG-1041), Diabli Kamień Mt. (FG-1041), 1957-62, leg. T. Sulma (UGDA; Polakowska 2002). 
Cladonia cf. parasitica (Hoffm.) Hoffm.

On soil. Collecting site: 2 . (!)

\section{Cladonia phyllophora Hoffm.}

On boulder; Diabli Kamień Mt. (FG-1041), 1954, leg. T. Sulma (UGDA; Polakowska 2002).

Cladonia pleurota (Flörke) Schaer.

On boulder and soil; Folusz - stream valley (FG-1041), Diabli Kamień Mt. (FG-1041), 1954-62, leg. T. Sulma (UGDA; Polakowska 2002).

\section{Cladonia pyxidata (L.) Hoffm.}

On wood of ash. Collecting site: 10.

Historical Data: Diabli Kamień Mt. (FG-1041), 195457, leg. T. Sulma (UGDA; Polakowska 2002).

\section{Cladonia ramulosa (With.) J. R. Laundon}

On apple tree stump. Collecting site: 10.

HistoricAl DATA: Folusz - stream valley (FG-1041), 1962, leg. T. Sulma (UGDA; Polakowska 2002).

\section{Cladonia rangiferina (L.) F. H. Wigg.}

On boulder and soil; Folusz - stream valley (FG-1041), Diabli Kamień Mt. (FG-1041), 1954-62, leg. T. Sulma (UGDA; Polakowska 2002).

\section{Cladonia rangiformis Hoffm.}

On boulder; Diabli Kamień Mt. (FG-1041), 1962, leg. T. Sulma (UGDA; Polakowska 2002).

\section{Cladonia squamosa Hoffm.}

On decaying stump, soil and boulder. Collecting sites: 1,15 .

Historical data: Folusz - stream valley (FG-1041), Diabli Kamień Mt. (FG-1041), 1936, 1954-62, leg. T. Sulma (UGDA; Polakowska 2002).

Cladonia subulata (L.) F. H. Wigg.

On soil, bark of fir, and wood. Collecting sites: 5, 14, $29,41,45$.

Coenogonium pineti (Ach.) Lücking \& Lumbsch Dimerella pineti (Ach.) Vězda

On bark of trees, epiphytic bryophytes and wood, on stone in one locality. Collecting sites: $1,2,5,6,7$, $8,9,12,15,16,19,24,28,29,30,34,35,38,50$, $52,53,54$.
Collema crispum (Huds.) F. H. Wigg.

On soil. Collecting site: 33. (!)

Note. In the Polish Carpathians the species is known only from the Góry Słonne Mts (Kiszka \& Piórecki 1992).

Collema tenax (Sw.) Ach. emend. Degel.

On clay soil; Wilsznia village (FG-2291), 1979, leg. J. Nowak (KRAM; Bielczyk 2003; Bielczyk \& Kozik 2009).

Cryptodiscus gloeocapsa (Nitschke ex Arnold) Baloch, Gilenstam \& Wedin

Bryophagus gloeocapsa Nitschke ex Arnold

On clay soil by forest road, between Magura Wątkowska Mt. and Kornuty Reserve (FG-1061), 1977, leg. J. Nowak (KRAM; Bielczyk 2003; Bielczyk \& Kozik 2009).

Dibaeis baeomyces (L.) Rambold \& Hertel

On soil. Collecting sites: 4, 5, 45, 48 .

Dictyocatenulata alba Finley \& E. F. Morris

On bark of beech. Collecting sites: 47, 55. (!)

Note. A lichenized species of basidiomycete, widespread worldwide. It is characterized by its white, elongated conidiophores aggregated in handle-shaped synnemata ended with \pm spherical conidial masses. In Poland known only from the Gorce Mts (where it is locally very numerous; Czarnota unpubl.); in the Carpathians recorded in Slovakia and Ukraine (Diederich et al. 2008). It mainly inhabits bases of stumps and protruding roots of beeches in natural forests.

Diploschistes gypsaceus (Ach.) Zahlbr.

On limestone; Olchowiec, by Wilsznia River (FG-2199), 1979, leg. J. Nowak (KRAM; Bielczyk 2002).

Diploschistes muscorum (Scop) R. Sant.

On soil; Diabli Kamień Mt. (FG-1041), 1954, leg. T. Sulma (UGDA; Polakowska 2002).

Diploschistes scruposus (Schreb.) Norman

On sandstone boulders; Diabli Kamień Mt. (FG-1041), Kornuty Reserve (EG-1969), 1955-62, leg. T. Sulma (UGDA; Sulma 1936; Polakowska 2002). 


\section{${ }^{*}$ Epigloea urosperma Döbbeler}

On thallus of Placynthiella sp. growing on rock. Collecting site: 4. (!)

Note. In the Carpathians the species was previously recorded only in the Babia Góra Massif (Czarnota \& Hernik 2013). Unlike other species in the genus, which usually are algicolous fungi, E. urosperma is a lichenicolous fungus associated in Poland with Placynthiella dasaea and P. uliginosa (Kukwa \& Flakus 2009; Czarnota \& Hernik 2013).

\section{Evernia divaricata (L.) Ach.}

On bark of beech; Kornuty Reserve (EG-1969) (Sulma 1936).

\section{Evernia mesomorpha Nyl.}

On bark of birch and fir, and on rock; Diabli Kamień Mt. (FG-1041), 1936, leg. T. Sulma (UGDA; Polakowska 2002).

\section{Evernia prunastri (L.) Ach.}

On bark of deciduous trees and shrubs, on pine and boulders. Collecting sites: 10, 27, 39, 44, 50, 58 .

Historical data: Folusz - stream valley (FG-1041), Diabli Kamień Mt. (FG-1041), Kornuty Reserve (EG1969), 1936, 1954-57, leg. T. Sulma (UGDA; Sulma 1936; Polakowska 2002).

\section{Flavoparmelia caperata (L.) Hale}

On epilithic mosses, bark of pine, fir and beech; Folusz - stream valley (FG-1041), Diabli Kamień Mt. (FG1041), Kornuty Reserve (EG-1969), 1936, 1954-62, leg. T. Sulma (UGDA; Sulma 1936; Sulma \& Fałtynowicz 1988; Polakowska 2002).

\section{Fuscidea arboricola Coppins \& Tønsberg}

On bark of sycamore. Collecting site: 15. (!)

Note. This sorediate, sterile lichen was collected in the Pogórze Dynowskie foothills in the early $21^{\text {st }}$ century but was not reported then (Czarnota unpubl.; GPN). Probably overlooked, but in the mountains certainly not as frequent as in the northern part of the country (e.g., Faltynowicz 2003; Łubek \& Jaroszewicz 2012 and literature cited therein). Known from the Eastern Carpathians in Slovakia and Ukraine (Kondratyuk et al. 2003; Coppins et al. 2005) and Romania (Ardelean et al. 2013). A species new for the Western Carpathians.

\section{Fuscidea pusilla Tønsberg}

On bark of deciduous trees and fir. Collecting sites: 1 , $2,33,38$.

Historical data: Diabli Kamień Mt. (FG-1041), 1955, leg. T. Sulma (UGDA).

Graphis scripta (L.) Ach.

On bark of deciduous trees. Collecting sites: 5, 7, 8, 9, 12, 15, 16, 17, 18, 19, 22, 24, 28, 30, 34, 46, 52, 53, 54.

HistORICAL DATA: Folusz - stream valley (FG-1041), Diabli Kamień Mt. (FG-1041), Kornuty Reserve (EG1969), 1954-57, leg. T. Sulma (UGDA; Sulma 1936; Sulma \& Fałtynowicz 1988; Polakowska 2002).

Gyalecta ulmi (Sw.) Zahlbr.

On bark of elm in forest; Skarpoty (FG-2079), 1979, leg. R. Kozik \& J. Nowak (KRAM; Nowak 1995; Bielczyk \& Kozik 2009).

Halecania viridescens Coppins \& $\mathrm{P}$. James

On bark of ash. Collecting site: 1. (!)

Note. A sterile species resembling Rinodina efflorescens Malme and $R$. griseosoralifera, both of which develop similar bluish-grey to brownish external soredia. The two taxa can be easily distinguished from Halecania viridescens chemically: Rinodina efflorescens contains pannarin and zeorin as major secondary compounds and $R$. griseosoralifera contains atranorin and zeorin, whereas Halecania viridescens produces argopsin and 'gracilenta unknown 1'. In Poland the species is reported from the northern part of the country (Kukwa \& Jabłońska 2009; Schiefelbein et al. 2012). A species new for the Polish Carpathians.

Hydropunctaria rheitrophila (Zschacke) Keller, Gueidan \& Thüs

Verrucaria rheitrophila Zschacke

On stones in stream and on wet rock. Collecting sites: $7,8,40$.

HistoriCAL DATA: Rostajne (FG-2075), Las Słodki (FG2077), 1979; leg. J. Nowak (KRAM; Krzewicka 2009).

\section{Hypocenomyce scalaris (Ach.) M. Choisy}

On bark of trees, on wood. Collecting sites: 1, 2, 10, $11,14,15,16,17,19,21,22,26,27,29,30,38,39$, 41, 44, 45, 49, 50, 56, 57. 


\section{Hypogymnia physodes (L.) Nyl.}

On bark of trees and shrubs, on wood, boulders and epilithic bryophytes. Collecting sites: 1, 2, 5, 6, 10, 11, $14,15,16,17,18,19,22,26,27,28,29,30,31,33$, 34, 35, 39, 41, 42, 44, 45, 49, 50, 53, 56, 57.

Historical DATA: Folusz - stream valley (FG-1041), Diabli Kamień Mt. (FG-1041), Kornuty Reserve (EG1969), 1936, 1954-62, leg. T. Sulma (UGDA; Sulma 1936; Polakowska 2002).

\section{Hypogymnia tubulosa (Schaer.) Hav.}

On bark of deciduous trees, pine, fir and larch, on wood. Collecting sites: 5, 27, 29, 39, 42 .

Historical Data: Diabli Kamień Mt. (FG-1041), 1954 62, leg. T. Sulma (UGDA; Polakowska 2002).

Hypotrachyna afrorevoluta (Krog \& Swinscow) Krog \& Swinscow

On rock; Diabli Kamień Mt. (FG-1041), 1954, leg. T Sulma (UGDA; Flakus \& Kukwa 2009).

\section{Imshaugia aleurites (Ach.) S. L. F. Meyer}

On bark of birch, fir and pine. Collecting site: 2 .

Historical DATA: Folusz - stream valley (FG-1041), Diabli Kamień Mt. (FG-1041), 1936, 1954-62, leg. T. Sulma (UGDA; Polakowska 2002).

\section{*Intralichen lichenicola (M. S. Christ.}

\section{\& D. Hawksw.) D. Hawksw. \& M. S. Cole}

On thallus and apothecia of Candelariella aurella growing on concrete. Collecting site: 42 . (!)

Note. The species is distingushed by its multicellular conidia arising as elongate chains of cells. It is much less frequent than I. christiansenii, which is characterized by its 1-septate conidia. I. lichenicola was previously reported from Europe (Greenland, Luxemburg, Norway, Spain, Svalbard, Sweden), Asia (Siberia) (Hawksworth $\&$ Cole 2002) and North America (California) (Kocourková et al. 2012). Here it is newly reported for Poland and the Carpathian range.

Ionaspis ceracea (Arnold) Hafellner \& Türk

On sandstone rocks; Huta Krempska (FG-2162), 1979, leg. J. Nowak (KRAM; Bielczyk 2003).

\section{Lecania cyrtella}

On bark of ash and willow. Collecting sites: 12, 33, 56. (!)

\section{Lecania erysibe (Ach.) Mudd}

On sandstone in structure of old bridge. Collecting site: 43. (!)

Lecanora albella (Pers.) Ach.

On bark of beech and fir; Folusz - stream valley (FG1041), Kornuty Reserve (EG-1969), 1957, leg. T. Sulma (UGDA; Sulma 1936; Polakowska 2002).

\section{Lecanora albellula Nyl.}

L. piniperda Körb.

On bark of ash and willow. Collecting sites: 10, 11, 33. (!)

\section{Lecanora albescens (Hoffm.) Flörke}

On concrete. Collecting sites: 15, 33, 46, 49.

\section{Lecanora argentata (Ach.) Malme}

On bark of beech, fir, sycamore and rowan. Collecting sites: $12,15,16,18,19$.

Historical DATA: Folusz - stream valley (FG-1041), Diabli Kamień Mt. (FG-1041), 1955-62, leg. T. Sulma (UGDA; Polakowska 2002).

\section{Lecanora carpinea (L.) Vain.}

On bark of beech, hornbeam and alder. Collecting sites: 15, 18, 19, 23, 35, 46.

Historical DATA: Folusz - stream valley (FG-1041), Diabli Kamień Mt. (FG-1041), 1954-57, leg. T. Sulma (UGDA; Polakowska 2002).

\section{Lecanora chlarotera Nyl.}

On bark of deciduous trees and fir, on wood. Collecting sites: $2,10,15,23,26,31,34,50,52,53,58$.

Historical Data: Diabli Kamień Mt. (FG-1041), 1954, leg. T. Sulma (UGDA; Polakowska 2002).

Lecanora conizaeoides Nyl. ex Cromb.

On bark of trees, on wood. Collecting sites: 1, 2, 5, 6, $7,8,9,10,12,14,15,16,17,19,21,22,24,25,26$, $27,28,29,30,31,34,35,38,39,41,42,44,45,47$, $48,49,50,52,56$.

\section{Lecanora crenulata Hook.}

On concrete. Collecting sites: $33,41$.

Lecanora dispersa (Pers.) Sommerf.

On concrete, boulders, sandstone, fir and willow. Collecting sites: 29, 31, 33, 34, 28, 50. 
Historical data: Diabli Kamień Mt. (FG-1041), 1954, leg. T. Sulma [UGDA; Polakowska 2002 as Lecanora umbrina (Ach.) A. Massal.]

\section{Lecanora expallens Ach.}

On bark of fir, willow, pear tree and sycamore. Collecting sites: $38,44,46,50$.

Historical data: Folusz - stream valley (FG-1041), Diabli Kamień Mt. (FG-1041), 1954-62, leg. T. Sulma (UGDA; Polakowska 2002).

\section{Lecanora hagenii (Ach.) Ach.}

On concrete. Collecting sites: 33, 43, 46, 50.

Lecanora glabrata (Ach.) Malme

On bark of fir; Folusz - stream valley (FG-1041), 1957, leg. T. Sulma (UGDA; Polakowska 2002).

Lecanora intricata (Ach.) Ach.

On sandstone boulders; Kornuty Reserve (EG-1969) (Sulma 1936).

Lecanora muralis (Schreb.) Rabenh.

On sandstone. Collecting site: 50.

Lecanora persimilis (Th. Fr.) Nyl.

On bark of sycamore. Collecting site: 58 . (!)

Lecanora polytropa (Hoffm.) Rabenh.

On sandstone. Collecting sites: 33, 51, 56.

Historical Data: Diabli Kamień Mt. (FG-1041), 1957, leg. T. Sulma (UGDA; Polakowska 2002).

\section{Lecanora pulicaris (Pers.) Ach.}

On bark of deciduous trees, pine and fir. Collecting sites: 1, 10, 15, 16, 17, 19, 22, 23, 26, 28, 33, 34, 35, 39, 53. Historical DATA: Folusz - stream valley (FG-1041), Diabli Kamień Mt. (FG-1041), 1954-62, leg. T. Sulma (UGDA; Polakowska 2002).

Lecanora rupicola (L.) Zahlbr.

On boulder; Diabli Kamień Mt. (FG-1041), 1957, leg. T. Sulma (UGDA; Polakowska 2002).

Lecanora saligna (Schrad.) Zahlbr. s.l.

On bark of deciduous trees and wood. Collecting sites: 16, 39, 41, 50, 56, 57.

Historical Data: Folusz - stream valley (FG-1041),
Diabli Kamień Mt. (FG-1041), 1954, leg. T. Sulma (UGDA; Polakowska 2002).

Lecanora semipallida H. Magn.

On sandstone and concrete. Collecting sites: 33, 42, 46, 50. (!)

Lecanora sulphurea (Hoffm.) Ach.

On boulder; Diabli Kamień Mt. (FG-1041), 1936, leg.

T. Sulma (UGDA; Polakowska 2002).

Lecanora symmicta (Ach.) Ach.

On wood and bark of deciduous trees. Collecting sites: $10,11,27,39,40$.

\section{Lecidella carpathica Körb.}

On rock. Collecting site: 2.

Historical Data: Diabli Kamień Mt. (FG-1041), 1955, leg. T. Sulma (UGDA; Polakowska 2002).

\section{Lecidella elaeochroma (Ach.) M. Choisy}

On wood and bark of deciduous trees. Collecting sites: 10, 15, 16, 26, 34, 41, 46, 44, 47.

Historical DATA: Folusz - stream valley (FG-1041), 1957, leg. T. Sulma (UGDA; Polakowska 2002).

\section{Lecidella flavosorediata (Vězda) Hertel}

\& Leuckert

On bark of deciduous trees and fir. Collecting sites: $33,44,58$.

Historical DatA: Diabli Kamień Mt. (FG-1041), 1954, leg. T. Sulma (UGDA; Polakowska 2002); Świerzowa Ruska (FG-2003), Czarne near Nieznajowa (FG-2082), 1979, leg. J. Nowak (KRAM; Bielczyk 2003).

Note. A usually sterile, sorediate lichen, $\mathrm{C}+$ orange due to the presence of xanthones (arthothelin, granulosin) in the thallus. It resembles some other species, often accompanying it, which show similar reactions (e.g., Lecanora expallens, L. compallens, Lecidella subviridis) but differs chemically (see, e.g., Purvis \& James 2009). Sometimes it forms black, shimmering at least initially, margined apothecia. In the Polish Carpathians known from the Beskid Żywiecki Mts (Czarnota \& Kukwa 2004), Gorce Mts (Czarnota 2010) and Tatras (Śliwa \& Kukwa 2012), as well as the Góry Sanocko-Turczańskie Mts and Bieszczady Mts (Kościelniak \& Kiszka 2003). 
Certainly more frequent in this part of Poland than reported in the published data.

Lecidella scabra (Taylor) Hertel \& Leuckert

On sandstone. Collecting site: 50. (!)

\section{Lecidella stigmatea (Ach.) Hertel \& Leuckert}

On concrete, sandstone and granite post. Collecting sites: 41, 46, 50, 56 .

\section{Lecidella subviridis Tønsberg}

On bark of sycamore and birch. Collecting sites: 1, 2. (!)

Note. A sorediate, yellowish-green lichen known in Poland only in its sterile form. The thallus contains xanthones (thiophanic acid, arthothelin, expallens unknown, which stain $\mathrm{KC}+$ orange) and atranorin, which distinguish this species from several other species that are morphologically similar (e.g., Lecidella flavosorediata, Lecanora compallens, Micarea viridileprosa). Previously noted in the Polish Carpathians from the Gorce Mts, Babia Góra Massif and the Tatras (Czarnota \& Kukwa 2004; Czarnota 2010, 2012; Śliwa \& Kukwa 2012); definitely much more widespread. Also reported from the Eastern Carpathians in Romania (Ardelean et al. 2013).

Leimonis erratica (Körb.) R. C. Harris \& Lendemer Micarea erratica (Körb.) Hertel, Rambold \& Pietschmann

On sandstone rocks. Collecting sites: 50, 51. (!)

Lepraria crassissima (Hue) Lettau

On rock; Diabli Kamień Mt. (FG-1041), 1957, leg. T. Sulma (UGDA; Polakowska 2002).

Lepraria eburnea J. R. Laundon

On concrete and bark of poplar. Collecting sites: 1, 50. (!)

\section{Lepraria elobata Tønsberg}

On bark of deciduous trees and fir, wood and sandstone boulders. Collecting sites: 1, 2, 5, 7, 8, 15, 17, 24, 27, $35,38,46,42,50,52$.

Historical DATA: Folusz - stream valley (FG-1041), 1957, leg. T. Sulma (UGDA; Polakowska 2002).
Lepraria finkii (de Lesd.) R. C. Harris

L. lobificans auct. non Nyl.

On bark of deciduous trees, epiphytic and epilithic bryophytes, wood, concrete and rock. Collecting sites: 1, 2, $5,7,9,10,11,12,13,15,16,17,18,19,24,26,29$, 30, 31, 33, 34, 43, 44, 51, 53.

Historical DATA: Folusz - stream valley (FG-1041), 1957, leg. T. Sulma (UGDA; Polakowska 2002).

Lepraria incana (L.) Ach.

On bark of deciduous and coniferous trees, wood, rock and concrete. Collecting sites: 2, 6, 10, 13, 15, 17, 19, 25, 26, 29, 31, 34, 38.

Historical DATA: Folusz - stream valley (FG-1041), 1954, leg. T. Sulma (UGDA; Polakowska 2002).

\section{Lepraria jackii Tønsberg}

On bark of deciduous trees, fir and pine, on wood and boulder. Collecting sites: 6, 16, 17, 21, 31, 34, 38 .

Historical Data: Diabli Kamień Mt. (FG-1041), 1954, leg. T. Sulma (UGDA; Polakowska 2002).

Lepraria membranacea (Dicks.) Vain.

On humus; Diabli Kamień Mt. (FG-1041), 1954, leg. T. Sulma (UGDA).

\section{Lepraria neglecta (Nyl.) Lettau}

Lepraria caesioalba (B. de Lesd.) J. R. Laundon On rock and on bark of fir. Collecting site: 2 .

Historical Data: Diabli Kamień Mt. (FG-1041), 1954 55, leg. T. Sulma (UGDA; Polakowska 2002).

Lepraria rigidula (B. de Lesd.) Tønsberg

On bark of deciduous trees and fir, on wood. Collecting sites: 10, 35, 42, 50 .

Historical Data: Diabli Kamień Mt. (FG-1041), 1954 57, leg. T. Sulma (UGDA; Polakowska 2002).

Lepraria vouauxii (Hue) R. C. Harris

On bark of deciduous trees, on rock. Collecting sites: $2,7,10,11,27,44,46$. (!)

\section{${ }^{\#}$ Licea parasitica (Zukal) Martin}

On thallus of Biatora epixanthoides growing on bark of beech. Collecting site: 15 . (!)

Note. A facultatively lichenicolous myxomycete. It is known from a few lowland sites in Poland (Czyżewska \& Kukwa 2009) and was also 
recorded from the Polish Carpathians but only in the Kotlina Orawsko-Nowotarska basin (Kukwa \& Jabłońska 2008).

\section{${ }^{*}$ Lichenoconium erodens M. S. Christ.}

\& D. Hawksw.

On Lecanora conizaeoides (thalli and apothecia) and on thalli of Hypocenomyce scalaris, Hypogymnia physodes and Pseudevernia furfuracea growing on bark of trees and on wood. Collecting sites: 2, 6, 8, 12, 37.

Historical DATA: Folusz - stream valley (FG-1041), 1954, leg. T. Sulma (UGDA; Polakowska 2002, Kukwa 2005).

${ }^{*}$ Lichenoconium lecanorae (Jaap) D. Hawksw.

On apothecia of Lecanora conizaeoides growing on bark of trees. Collecting sites: $1,2,6,9,10,25,34,35,38$.

\section{*Lichenodiplis lecanorae (Vouaux) Dyko}

\& D. Hawksw.

On Caloplaca sp. growing on concrete. Collecting site: 50. (!)

Loxospora elatina (Ach.) A. Massal.

On bark of sycamore and pine. Collecting sites: 29, 34. (!)

Melanelixia glabratula (Lamy) Sandler \& Arup M. fuliginosa subsp. glabratula (Lamy) J. R. Laundon, Melanelia fuliginosa subsp. glabratula (Lamy) Coppins On bark of deciduous trees. Collecting sites: 1, 7, 10, $11,12,13,15,26,27,29,33,34,35,38,40,42,44$, $46,49,50,52,53$.

Historical DATA: Folusz - stream valley (FG-1041), Diabli Kamień Mt. (FG-1041), 1954-62, leg. T. Sulma (UGDA; Polakowska 2002).

Melanelixia subaurifera (Nyl.) O. Blanco, A. Crespo, Divakar, Essl., D. Hawksw. \& Lumbsch

Melanelia subaurifera (Nyl.) Essl.

On bark of fir, beech and sycamore. Collecting sites: $15,16,39$.

Historical DATA: Folusz - stream valley (FG-1041), Diabli Kamień Mt. (FG-1041), 1954-57, leg. T. Sulma (UGDA; Polakowska 2002).

Melanohalea elegantula (Zahlbr.) O. Blanco,

A. Crespo, Divakar, Essl., D. Hawksw. \& Lumbsch Melanelia elegantula (Zahlbr.) Essl.
On bark of apple tree. Collecting site: 10 .

Melanohalea exasperatula (Nyl.) O. Blanco, A. Crespo, Divakar, Essl., D. Hawksw. \& Lumbsch Melanelia exasperatula (Nyl.) Essl.

On bark of deciduous trees. Collecting sites: 26, 27, 28, 29, 30, 31, 33, 34, 56.

Menegazzia terebrata (Hoffm.) Körb.

On bark of beech; Folusz - stream valley (FG-1041), Diabli Kamień Mt. (FG-1041), Kornuty Reserve (EG1969), 1954-62, leg. T. Sulma (UGDA; Sulma 1936; Sulma \& Fałtynowicz 1988; Polakowska 2002).

Micarea botryoides (Nyl.) Coppins

On wood and in one locality on rock. Collecting sites: 2, 7, 8, 21, 29. (!)

Micarea denigrata (Fr.) Hedl.

On wood and sandstone boulder. Collecting sites: 39 , 41,50 .

Historical DATA: Nieznajowa (FG-2073), 1985, leg. L. Lipnicki (Czarnota 2007); Skarpoty (FG-2079), 1979, leg. J. Nowak (KRAM; Czarnota 2007).

Micarea lithinella (Nyl.) Hedl.

On small sandstone rocks and on boulder in forest. Collecting sites: $12,38,46,47,48$. (!)

Micarea micrococca (Körb.) Gams ex Coppins

On bark of deciduous trees and fir, on wood. Collecting sites: $2,7,6,8,15,17,19,21,24,26,29,48,53,54$. (!)

Micarea misella (Nyl.) Hedl.

On wood. Collecting sites: 15, 51.

Historical DATA: Nieznajowa (FG-2073), 1979, leg. J. Nowak (KRAM; Czarnota 2007).

Micarea nitschkeana (Lahm ex Rabenh.) Harm. On bark of ash. Collecting site: 53 .

Micarea peliocarpa (Anzi) Coppins \& R. Sant.

On small sandstone rocks and on larger rock. Collecting sites: 2, 47.

Historical Data: Folusz - stream valley (FG-1041), 1954, leg. T. Sulma (UGDA; Polakowska 2002).

Micarea prasina Fr. s.l.

incl. M. prasina Fr. s.str. 
On wood and bark of pine, on decayed fir. Collecting sites: $1,2,5,6,7,9,8,15,17,19,21,24,34,35,38$, $47,51,52,54$.

Historical data: Cyrla Mt. NE slope (FG-2057), 1979, leg. J. Nowak (KRAM; Czarnota 2007).

Note. Because the majority of data come from notes taken in the field, the taxon is treated sensu lato.

Micarea viridileprosa Coppins \& van den Boom On sandstone rock. Collecting site: 2. (!)

Note. A sterile, sorediate species characterized by the presence of gyrophoric acid, the thallus of which gives a $\mathrm{C}+$ red reaction. The species is widespread in Western Europe. So far recorded in the Polish Carpathians only in their western part, but in the Polish lowlands it is locally frequent at the base of pines in coniferous forests (Czarnota 2007). Recently also found in the Eastern Carpathians in Romania (Ardelean et al. 2013).

\section{"Monodictys epilepraria Kukwa \& Diederich}

On Lepraria cf. incana growing on sycamore. Collecting site: 38. (!)

Note. A representative of the lichenicolous hyphomycetes characterized by its small, brown, muriform, smooth-walled conidia developing on discolored patches of the host (Lepraria spp.). The species is relatively widespread in Poland, recorded from numerous lowland sites (Kukwa \& Diederich 2005; Czyżewska \& Kukwa 2009; Schiefelbein et al. 2012; Kowalewska \& Kukwa 2013; Kukwa et al. 2013) and mountain ranges including the Karkonosze Mts, Beskid Sądecki Mts, Gorce Mts, Babia Góra Massif and the Bieszczady Mts (Kukwa \& Diederich 2005; Kukwa \& Flakus 2009; Kukwa et al. 2010).

Montanelia disjuncta (Erichsen) Divakar, A. Crespo, Wedin \& Essl.

Melanelia disjuncta (Erichsen) Essl.

On sandstone rock. Collecting site: 2.

Historical data: Diabli Kamień Mt. (FG-1041), 1954, leg. T. Sulma (UGDA; Sulma, Fałtynowicz 1988; Polakowska 2002).
Multiclavula mucida (Pers.) R. H. Petersen

On decaying wood of fir. Collecting site: 47. (!)

Note. A lichenized fungus of the Basidiomycota, with an inconspicuous, thin, membrane-like thallus and club-shaped, white-cream basidiocarps up to $c a 1 \mathrm{~cm}$ high. The fruiting bodies are ephemeral; probably this is why its distribution is poorly known. Reported from one locality in the Polish lowland (Czyżewska et al. 2005) and three localities in the Bieszczady Mts (Kościelniak 2013). Known from the Western Carpathians in Slovakia (Guttová \& Palice 1999; Lisická 2005; Guttová et al. 2012) and the Eastern Carpathians in Ukraine (Vondrák et al. 2010a; Dymytrova et al. 2013).

\section{${ }^{+}$Mycocalicium subtile (Pers.) Szatala}

On wood of fir. Collecting sites: 7, 24, 34.

Historical DATA: Nieznajowa (FG-2063), 1979, leg. J. Nowak (KRAM; Bielczyk 2003).

${ }^{+}$Mycomicrothelia confusa D. Hawksw.

On bark of alder. Collecting site: 35 . (!)

Note. A species reported from a few localities in Europe (e.g., Hawksworth \& Orange 2009). Although known from the Sudetes Mts from historical records (Fałtynowicz 2003), it is new for the Polish Carpathians.

Nephroma parile (Ach.) Ach.

Habitat not given; Folusz - stream valley (FG-1041), 1955, leg. T. Sulma (UGDA; Polakowska 2002).

Normandina pulchella (Borrer) Nyl.

On bark of apple tree in abandoned orchard and on bark of willow by river. Collecting sites: 20, 44 .

Historical data: Folusz - stream valley (FG-1041), 1955, leg. T. Sulma (UGDA; Fałtynowicz 1999).

Ochrolechia androgyna (Hoffm.) Arnold

On bark of sycamore, beech and fir. Collecting site: 31 .

Historical Data: Diabli Kamień Mt. (FG-1041), 1954 55, leg. T. Sulma (UGDA; Polakowska 2002; Kukwa 2011).

Ochrolechia arborea (Kreyer) Almb.

On bark of beech and fir; Diabli Kamień Mt. (FG-1041), 1954-55, leg. T. Sulma (UGDA; Kukwa 2011). 


\section{Ochrolechia microstictoides Räsänen}

On bark of fir; Folusz - stream valley (FG-1041), s.d., leg. T. Sulma (UGDA; Polakowska 2002).

Opegrapha niveoatra (Borrer) J. R. Laundon

O. vulgata var. subsiderella $\mathrm{Nyl}$.

On bark of sycamore. Collecting site: 38 .

Opegrapha vermicellifera (Kunze) J. R. Laundon On bark of beech and hornbeam; Nieznajowa (FG2063), Las Słodki FG-2068, 1979, leg. J. Nowak (KRAM; Bielczyk 2003).

\section{Parmelia omphalodes (L.) Ach.}

On boulder. Collecting site: 2 .

Historical DATA: Folusz - stream valley (FG-1041), Diabli Kamień Mt. (FG-1041), 1954-62, leg. T. Sulma (UGDA; Polakowska 2002).

\section{Parmelia saxatilis (L.) Ach. s.l.}

On bark of deciduous trees, fir and pine, on rock. Collecting sites: 2, 10, 15, 16, 28, 31, 39.

Historical DATA: Folusz - stream valley (FG-1041), Diabli Kamień Mt. (FG-1041), Kornuty Reserve (EG1969), 1954-62, leg. T. Sulma (UGDA; Sulma 1936; Polakowska 2002).

Note. Because the majority of data come from notes taken in the field, the taxon was treated sensu lato.

\section{Parmelia submontana Nádv. ex Hale}

On bark of sycamore and beech, on boulder. Collecting site: 16 .

Historical DatA: Diabli Kamień Mt. (FG-1041), 1954; leg. T. Sulma (UGDA; Sulma \& Fałtynowicz 1988; Polakowska 2002).

\section{Parmelia sulcata Taylor}

Mainly on bark of deciduous trees and fir, rarely on wood and boulder. Collecting sites: 10, 11, 15, 16, 27, $28,29,31,33,34,35,37,38,39,41,42,44,46,50$, $56,58$.

Historical data: Folusz - stream valley (FG-1041), Diabli Kamień Mt. (FG-1041), Kornuty Reserve (EG-1969), 1936, 1954-62, leg. T. Sulma (UGDA; Sulma 1936; Sulma \& Fałtynowicz 1988; Polakowska 2002).

\section{Parmelina tiliacea (Hoffm.) Hale}

On bark of willow, beech and ash. Collecting site: 44 .

Historical data: Kornuty Reserve (EG-1969) (Sulma 1936); Nieznajowa (FG-2073), 1979; leg. J. Nowak (KRAM).

\section{Parmeliopsis ambigua (Wulfen) Nyl.}

On bark of deciduous trees, fir and pine. Collecting sites: $2,10,15,16,21,34,50,56$.

Historical Data: Folusz - stream valley (FG-1041), Diabli Kamień Mt. (FG-1041), 1954-62, leg. T. Sulma (UGDA; Polakowska 2002).

Peltigera didactyla (With.) J. R. Laundon

On soil; Folusz - stream valley (FG-1041), 1936; leg. T. Sulma (UGDA; Polakowska 2002); Nieznajowa (FG2073), 1985, leg. J. Nowak (KRAM; Bielczyk 2003; Bielczyk \& Kozik 2009).

\section{Peltigera praetextata (Sommerf.) Zopf}

On bryophytes growing on sandstone boulder. Collecting site: 54 .

Historical Data: Folusz - stream valley (FG-1041), 1954-55, leg. T. Sulma (UGDA; Polakowska 2002).

Peltigera rufescens (Weiss) Humb.

On soil. Collecting sites: 41, 49.

Pertusaria albescens (Huds.) M. Choisy \& Werner On bark of deciduous trees and fir. Collecting sites: 10 , 16, 27, 31, 33, 37, 39, 45, 44, 46.

Historical Data: Folusz - stream valley (FG-1041), Diabli Kamień Mt. (FG-1041), 1954-55, leg. T. Sulma (UGDA; Polakowska 2002).

\section{Pertusaria amara (Ach.) Nyl.}

On bark of deciduous trees and fir. Collecting sites: 9 , $15,16,17,18,33,41$.

Historical Data: Folusz - stream valley (FG-1041), Diabli Kamień Mt. (FG-1041), 1954-57, leg. T. Sulma (UGDA; Polakowska 2002); Skarpoty (FG-2079), 1979, leg. J. Nowak (KRAM).

Pertusaria aspergilla (Ach.) J. R. Laundon

$P$. dealbescens auct.

On boulder; Diabli Kamień Mt. (FG-1041), 1955, leg.

T. Sulma (UGDA; Polakowska 2002). 
Pertusaria coccodes (Ach.) Nyl.

On bark of beech and fir; Folusz - stream valley (FG1041), Diabli Kamień Mt. (FG-1041), Kornuty Reserve (EG-1969), 1954-57, leg. T. Sulma (UGDA; Sulma 1936; Polakowska 2002).

Pertusaria coronata (Ach.) Th. Fr.

On bark of pine, beech and sycamore; Diabli Kamień Mt. (FG-1041), 1957, leg. T. Sulma (UGDA; Polakowska 2002); Niedźwiedzie FG-2180, 1979, leg. J. Nowak (KRAM).

\section{Pertusaria leioplaca DC.}

On bark of beech. Collecting sites: 22, 54 .

Pertusaria ocellata Körb.

Substrate not given; Diabli Kamień Mt. (FG-1041), 1962, leg. T. Sulma (UGDA; Polakowska 2002).

Pertusaria pertusa (Weigel) Tuck.

On bark of beech and sycamore. Collecting sites: 16 , $17,19,34$.

Historical Data: Las Słodki FG-2068, Skarpoty (FG2079), 1979, leg. J. Nowak (KRAM).

Pertusaria pupillaris (Nyl.) Th. Fr.

On bark of fir; Diabli Kamień Mt. (FG-1041), 1962, leg. T. Sulma (UGDA; Polakowska 2002).

\section{Phaeophyscia nigricans (Flörke) Moberg}

On concrete and willow. Collecting sites: 28, 41, 46.

\section{Phaeophyscia orbicularis (Necker) Moberg}

On bark of deciduous trees and concrete. Collecting sites: 10, 28, 34, 41, 42, 50, 58.

Historical DATA: Folusz - stream valley (FG-1041), 1957, leg. T. Sulma (UGDA; Polakowska 2002).

"Phaeopyxis punctum (A. Massal.) Rambold, Triebel \& Coppins

On Cladonia sp.; Diabli Kamień Mt. (FG-1041), s.d., leg. T. Sulma (UGDA; Kukwa 2005).

Phlyctis argena (Spreng.) Flot.

On bark of deciduous trees. Collecting sites: 10, 14, $15,16,17,18,19,27,31,33,34,38,39,41,44,46$, $50,53,56,57,58$.

Historical DATA: Folusz - stream valley (FG-1041), Diabli Kamień Mt. (FG-1041), 1954-57, leg. T. Sulma
(UGDA; Polakowska 2002); Skarpoty (FG-2079), 1979, leg. J. Nowak (KRAM; Bielczyk \& Kozik 2009).

\section{Physcia adscendens (Fr.) H. Olivier}

On bark of deciduous trees, on wood and concrete. Collecting sites: 1, 10, 28, 33, 39, 41, 42, 46, 50, 56, 58 .

Historical DATA: Folusz - stream valley (FG-1041), 1954, leg. T. Sulma (UGDA; Polakowska 2002); Wilsznia village (FG-2291), 1979, leg. J. Nowak (KRAM; Nowak 1993; Bielczyk \& Kozik 2009).

Physcia aipolia (Ehrh. ex Humb.) Fümb.

On bark of ash; Nieznajowa (FG-2073), 1979, leg. J. Nowak (KRAM; Nowak 1993).

Physcia caesia (Hoffm.) Fürnr.

On wood and concrete. Collecting sites: 33, 42.

Physcia dubia (Hoffm.) Lettau

On sandstone, on bark of deciduous trees. Collecting sites: 33, 34, 41, 56.

Historical Data: Świerzowa Ruska (FG-2003), Wilsznia village (FG-2291), 1979, leg. J. Nowak (KRAM; Nowak 1993).

\section{Physcia stellaris (L.) Nyl.}

On bark of willow and poplar. Collecting site: 33 .

Historical data: Folusz - stream valley (FG-1041), 1954, leg. T. Sulma (UGDA; Polakowska 2002).

\section{Physcia tenella (Scop.) DC.}

On bark of deciduous trees, on concrete. Collecting sites: $10,20,27,28,29,33,36,38,39,41,42,50,56,57,58$.

Historical Data: Folusz - stream valley (FG-1041), 1954, leg. T. Sulma (UGDA; Polakowska 2002).

Physconia distorta (With.) J. R. Laundon

On bark of ash and willow; Folusz - stream valley (FG1041), s.d., leg. T. Sulma (UGDA; Polakowska 2002); Świerzowa Ruska (FG-2003), Nieznajowa (FG-2073), 1979, leg. J. Nowak (KRAM; Nowak 1993; Bielczyk \& Kozik 2009).

\section{Physconia enteroxantha (Nyl.) Poelt}

On bark of deciduous trees. Collecting sites: 41, 50.

Historical DATA: Nieznajowa (FG-2073), 1979, leg. J. Nowak (KRAM; Nowak 1993). 
Physconia grisea (Lam.) Poelt

On bark of sycamore; Folusz - stream valley (FG1041), 1954, leg. T. Sulma (UGDA; Polakowska 2002); Żydowskie (FG-2089), 1979, leg. J. Nowak (KRAM; Nowak 1993).

Physconia perisidiosa (Erichsen) Moberg

On bark of old willow; Nieznajowa (FG-2073), 1979, leg. J. Nowak (KRAM; Nowak 1993; Bielczyk \& Kozik 2009).

\section{Placynthiella dasaea (Stirt.) Tønsberg}

On wood, humus and bark of trees. Collecting sites: 1, $2,6,7,8,15,21,27,31,35,40,41,48,51,50$.

Historical Data: Folusz - stream valley (FG-1041), 1962, leg. T. Sulma (UGDA; Polakowska 2002).

Placynthiella icmalea (Ach.) Coppins \& P. James On wood, humus and bark of trees. Collecting sites: 2 , 8, 14, 15, 16, 21, 31, 38, 40, 50, 56.

Historical Data: Diabli Kamień Mt. (FG-1041), 1955, leg. T. Sulma (UGDA; Polakowska 2002).

\section{Placynthiella uliginosa (Schrad.) Coppins}

\& P. James

On decaying stumps; Diabli Kamień Mt. (FG-1041), 1955, leg. T. Sulma (UGDA; Polakowska 2002); Świerzowa Ruska (FG-2003), Nieznajowa (FG-2064), Skarpoty (FG-2079), Huta Krempska (FG-2162), 1979, leg. J. Nowak (KRAM; Bielczyk \& Kozik 2009).

Platismatia glauca (L.) W. L. Culb. \& C. F. Culb. On bark of pine, birch, ash and sycamore. Collecting sites: 15,44 .

Historical Data: Folusz - stream valley (FG-1041), Diabli Kamień Mt. (FG-1041), Kornuty Reserve (EG1969), 1936, 1954-62, leg. T. Sulma (UGDA; Sulma 1936; Polakowska 2002).

\section{Polycauliona candelaria (L.) Frödén, Arup}

\& Søchting

Xanthoria candelaria (L.) Th. Fr.

On bark of ash. Collecting site: 41 .

Polycauliona polycarpa (Hoffm.) Frödén, Arup \& Søchting

Xanthoria polycarpa (Hoffm.) Rieber

On bark of deciduous trees, on wood. Collecting sites: 29, 33, 41, 44, 56, 57.
Historical DATA: Folusz - stream valley (FG-1041), s.d., leg. T. Sulma (UGDA; Polakowska 2002).

Polysporina simplex (Davies) Vězda

On sandstone boulder. Collecting site: 50 .

Polysporina subfuscescens (Nyl.) K. Knudsen \& Kocourk.

Polysporina lapponica auct. non (Schaer.) Degel

On sandstone boulder; Wilsznia village (FG-2291), 1979, leg. J. Nowak (KRAM).

Porina aenea (Wallr.) Zahlbr.

Pseudosagedia aenea (Wallr.) Hafellner \& Kalb

On bark of deciduous trees and fir, on wood, in one locality on sandstone. Collecting sites: 2, 5, 7, 9, $12,15,16,17,18,19,22,23,24,28,34,35,38$, $50,52,54$.

Historical Data: Krempna (FG-2151), 1979, leg. J. Nowak (KRAM; Bielczyk \& Kozik 2009).

Porina chlorotica (Ach.) Müll. Arg.

Pseudosagedia chlorotica (Ach.) Hafellner \& Kalb

On wet rocks and boulders. Collecting sites: 1, 3, 7, $9,35,50 .(!)$

Porpidia crustulata (Ach.) Hertel \& Knoph

On sandstone rocks, boulders and pebbles. Collecting sites: 5, 10, 11, 17, 20, 33, 34, 47, 48, 51, 56, 57.

Historical data: Diabli Kamień Mt. (FG-1041), 1954, leg. T. Sulma (UGDA; Polakowska 2002); Majdan Mt. (FG-1093), Krempna (FG-2140, 2151, 2152), 1979, leg. J. Nowak (KRAM; Bielczyk \& Kozik 2009).

Porpidia macrocarpa (DC.) Hertel \& A. J. Schwab. On sandstone. Collecting sites: 5, 33.

HistoricAl DATA: Kornuty Reserve (EG-1969) (Sulma 1936).

Porpidia soredizodes (Lamy ex Nyl.) J. R. Laundon On sandstone. Collecting sites: 2, 6, 7, 12, 15, 40.

Historical Data: Diabli Kamień Mt. (FG-1041), 1954, leg. T. Sulma (UGDA; Polakowska 2002).

Porpidia tuberculosa (Sm.) Hertel \& Knoph

On sandstone; Rostajne (FG-2074), 1979, leg. J. Nowak (KRAM; Bielczyk 2003; Bielczyk \& Kozik 2009). 
Protoblastenia rupestris (Scop.) J. Steiner

On calcareous stone. Collecting site: 33 .

Protoparmelia badia (Hoffm.) Hafellner

On sandstone boulders; Diabli Kamień Mt. (FG-1041), Kornuty Reserve (EG-1969), 1936, 1954-57, leg. T. Sulma (UGDA; Sulma 1936; Polakowska 2002).

\section{Pseudevernia furfuracea (L.) Zopf}

On bark of deciduous trees, pine and fir, less often on wood, on rock in one locality. Collecting sites: 2, 15, 16, 18, 19, 27, 29, 37, 39.

Historical DATA: Folusz - stream valley (FG-1041), Diabli Kamień Mt. (FG-1041), Kornuty Reserve (EG1969), 1936, 1954-62, leg. T. Sulma (UGDA; Sulma 1936; Polakowska 2002).

Pseudoschismatomma rufescens (Pers.) Ertz \& Tehler

Opegrapha rufescens Pers.

On bark of beech; Kornuty Reserve (EG-1969) (Sulma 1936).

\section{Psilolechia lucida (Ach.) M. Choisy}

On sandstone boulder. Collecting site: 15. (!)

\section{Punctelia jeckeri (Roum.) Kalb.}

On willows by stream. Collecting site: 32. (!)

Note. A relatively widespread foliose species occurring on various tree species, but not distinguished from $P$. subrudecta until recently (Kalb 2007); numerous Polish records of the latter species may refer to P. jeckeri (Kościelniak 2013).

\section{Punctelia subrudecta (Nyl.) Krog}

On bark of fir and ash; Diabli Kamień Mt. (FG-1041), 1954, leg. T. Sulma (UGDA; Polakowska 2002); Krempna (FG-2142), 1979, leg. J. Nowak (KRAM).

\section{Pyrenula nitida (Weigel) Ach.}

On bark of beech, hornbeam and sycamore. Collecting sites: $8,9,12,15,18,19,22,23,31,34,38,46,47$, 52,54 .

Historical data: Folusz - stream valley (FG-1041), Kornuty Reserve (EG-1969), 1957, leg. T. Sulma (UGDA; Sulma 1936; Polakowska 2002); Skarpoty (FG-2079), Krempna (FG-2152), Niedźwiedzie (FG2180), 1979, leg. J. Nowak (KRAM).
Ramalina farinacea (L.) Ach.

On bark of beech; Folusz - stream valley (FG-1041), 1955, leg. T. Sulma (UGDA; Polakowska 2002).

Ramalina fastigiata (Pers.) Ach.

On bark of beech; Folusz - stream valley (FG-1041), Kornuty Reserve (EG-1969), 1955, leg. T. Sulma (UGDA; Sulma 1936; Polakowska 2002).

Ramalina fraxinea (L.) Ach.

On bark of sycamore. Collecting site: 41 .

Historical Data: Folusz - stream valley (FG-1041), s.d., leg. T. Sulma (UGDA; Polakowska 2002).

Ramalina obtusata (Arnold) Bitter

On bark of fir; Folusz - stream valley (FG-1041), 1936, leg. T. Sulma (UGDA; Polakowska 2002).

Ramalina pollinaria (Westr.) Ach.

On bark of beech; Diabli Kamień Mt. (FG-1041), Kornuty Reserve (EG-1969), 1954, leg. T. Sulma (UGDA; Sulma 1936; Polakowska 2002).

Rhizocarpon badioatrum (Flörke ex Spreng.) Th. Fr. On stones. Collecting sites: 33, 56.

Rhizocarpon geographicum (L.) DC.

On sandstone. Collecting site: 56.

Historical Data: Diabli Kamień Mt. (FG-1041), Kornuty Reserve (EG-1969), 1936, leg. T. Sulma (UGDA; Sulma 1936; Polakowska 2002).

Rhizocarpon grande (Flörke) Arnold

On boulder; Diabli Kamień Mt. (FG-1041), 1954, leg. T. Sulma (UGDA; Polakowska 2002).

Rhizocarpon reductum Th. Fr.

Rhizocarpon obscuratum auct.

On sandstone. Collecting site: 56.

Historical Data: Diabli Kamień Mt. (FG-1041), 1954, leg. T. Sulma (UGDA; Polakowska 2002); Rostajne (FG2074), 1979, leg. J. Nowak (KRAM; Bielczyk \& Kozik 2009).

Rinodina exigua (Ach.) Gray

On bark of willow and alder. Collecting sites: 33, 56.

\section{Rinodina griseosoralifera Coppins}

On bark of apple tree. Collecting site: 39. (!) 
Note. A corticolous, sterile species characterized by its blue-grey soralia and the presence of atranorin and zeorin in the thallus. Buellia griseovirens is another common corticolous species with a similar tinge of the soralia, but they appear yellowish when abraded and its thallus contains atranorin and norstictic acid as major secondary compounds (Coppins 1989). In Poland Rinodina griseosoralifera is known from the Gorce Mts (Czarnota \& Kukwa 2007). Besides the Polish localities, for the whole Carpathian range it was recorded only in the Eastern Carpathians in Ukraine (Coppins et al. 2005).

\section{Rinodina oleae Bagl.}

R. gennarii Bagl.

On concrete. Collecting site: 50 .

Rusavskia elegans (Link) S. Y. Kondr. \& Kärnefelt. Xanthoria elegans (Link.) Th.Fr.

On concrete. Collecting sites: 41, 46.

\section{Sarcogyne regularis Körb.}

On concrete and stones. Collecting sites: 4, 37, 41. (!) Historical Data: Świerzowa Ruska (FG-2003), 1979, leg. J. Nowak (KRAM).

\section{Sarcosagium campestre var. macrosporum Coppins} \& P. James

On bark of elm and decaying stump of fir. Collecting site: 38 .

Historical data: Świerzowa Mt. (FG-1074); Nieznajowa (FG-2073), 1979, leg. J. Nowak (KRAM; Bielczyk 2003).

\section{${ }^{+}$Sarea difformis (Fr.) Fr.}

On resin on bark of larch. Collecting site: 1. (!)

Schaereria fuscocinerea (Nyl.) Clauzade \& Cl. Roux On rock. Collecting site: 2. (!)

Sclerophora nivea (Hoffm) Tibell

On bark of beech; Skarpoty (FG-2079), 1979, leg. J. Nowak (KRAM; Bielczyk 2003).

Scoliciosporum chlorococcum (Graewe ex Stenh.) Vězda

On bark of trees and bushes, rarely on wood. Collecting sites: $1,2,6,10,15,16,18,21,26,27,28,31,33,34$, 38,41 .

HistoriCAl DaTA: Diabli Kamień Mt. (FG-1041), 1954 62, leg. T. Sulma (UGDA; Polakowska 2002); Rostajne (FG-2074), Skarpoty (FG-2079), Krempna (FG-2151), 1979, leg. J. Nowak (KRAM).

\section{Scoliciosporum sarothamni (Vain.) Vězda}

On bark of deciduous trees and larch. Collecting sites: $1,5,10,36,38,44,53$. (!)

Scoliciosporum umbrinum (Ach.) Arnold

On sandstone. Collecting sites: 2, 17, 20, 50.

Stereocaulon vesuvianum Pers.

On boulder; Diabli Kamień Mt. (FG-1041), 1936, leg. T. Sulma (UGDA; Polakowska 2002).

*Stigmidium fuscatae (Arnold) R. Sant.

On Acarospora fuscata; Diabli Kamień Mt. (FG-1041), 1954, leg. T. Sulma (UGDA; Kukwa 2005).

Strangospora pinicola (A. Massal.) Körb.

On bark of sycamore and wood of pine. Collecting sites: 39, 40, 58. (!)

HistORICAL DATA: between Magura Wątkowska and Kornuty Reserve (FG-1061), 1977, leg. J. Nowak (KRAM).

Tephromela atra (Huds.) Hafellner

On boulder; Diabli Kamień Mt. (FG-1041), 1954, leg. T. Sulma (UGDA; Polakowska 2002).

\section{Thelidium minutulum Körb.}

On stone sprinkled with water. Collecting site: 40. (!)

\section{Thelocarpon epibolum Nyl.}

On decaying stump. Collecting site: 8 .

Historical Data: Niedźwiedzie (FG-2180), 1979, leg. J. Nowak (KRAM; Bielczyk 2003).

${ }^{+}$Thelocarpon lichenicola (Fuckel) Poelt \& Hafellner On sandstone. Collecting sites: 47, 50.

Note. This species is known from the Western Beskid Mts (Bielczyk 2003) and Góry Sanocko-Turczańskie Mts (Kościelniak 2004). In the Beskid Niski Mts (but outside MNP) it was found in the vicinity of Jaśliska (KRAM, Bielczyk 2003). 
Thelocarpon magnussonii G. Salisb.

On sandstone by stream; Żydowskie (FG-2180), 1979, leg. J. Nowak (KRAM; Bielczyk 2003; Bielczyk \& Kozik 2009).

\section{Thelocarpon robustum Eitner}

On sandstone by stream; Wyszowatka towards Rostajne (FG-2095), Żydowskie (FG-2180), 1979, leg. J. Nowak (KRAM).

\section{Thelopsis rubella Nyl.}

On bark of old beech; Krempna (FG-2069), 1977, leg. J. Nowak (KRAM; Bielczyk 2003).

\section{Trapelia coarctata (Sm.) M. Choisy}

On rock and sandstone. Collecting sites: 4, 5, 6, 7, 9, 13, 15, 17, 24, 31, 34, 36, 50, 51.

Historical Data: Świerzowa Ruska (FG-2003), Nieznajowa (FG-2073), Rostajne (FG-2074), Żydowskie (FG-2190), 1979, leg. J. Nowak (KRAM; Bielczyk \& Kozik 2009).

Trapelia glebulosa (Sm.) J. R. Laudon

Trapelia involuta (Taylor) Hertel

On sandstone rocks. Collecting sites: 4, 15, 31, 34, 47,48 .

Historical DatA: Diabli Kamień Mt. (FG-1041), 1955, leg. T. Sulma (UGDA; Polakowska 2002).

Trapelia obtegens (Th. Fr.) Hertel

On boulder in forest. Collecting site: 40. (!)

Trapelia placodioides Coppins \& P. James

On rock, boulders, stones and gravestone. Collecting sites: 2, 7, 6, 5, 1, 9, 12, 17, 50 .

Historical DATA: Żydowskie (FG-2089), 1979; leg. J. Nowak (KRAM; Bielczyk 2003: Bielczyk \& Kozik 2009).

Trapeliopsis flexuosa (Fr.) Coppins \& P. James

On wood and bark of trees, in one locality on boulder. Collecting sites: 1, 2, 13, 14, 15, 16, 26, 31, 34, 35, $36,39,50$.

Historical DatA: Diabli Kamień Mt. (FG-1041), 1957, leg. T. Sulma (UGDA; Polakowska 2002).

Trapeliopsis granulosa (Hoffm.) Lumbsch

On soil, bark of pine, wood. Collecting sites: 15, 19, 56. Historical Data: Folusz - stream valley (FG-1041),
Diabli Kamień Mt. (FG-1041), 1954-57, leg. T. Sulma (UGDA; Polakowska 2002).

Trapeliopsis pseudogranulosa Coppins \& P. James On soil, humus and rock waste. Collecting sites: 14, 15. Historical Data: Diabli Kamień Mt. (FG-1041), $1957-$ 63, leg. T. Sulma (UGDA; Polakowska 2002).

Trapeliopsis viridescens (Schrad.) Coppins \& P. James

On decaying stump; Diabli Kamień Mt. (FG-1041), 1957, leg. T. Sulma (UGDA; Polakowska 2002); Kornuty Reserve (EG-1979), 1974, leg. J. Nowak (KRAM; Bielczyk 2003; Bielczyk \& Kozik 2009).

\section{${ }^{*}$ Tremella cladoniae Diederich \& M. S. Christ.}

On thalli of Cladonia coniocraea growing on bark of hawthorn, on Cladonia chlorophaea on bark of ash. Collecting site: 10. (!)

*Tremella phaeophysciae Diederich \& M. S. Christ. On epiphytic thallus of Phaeophyscia orbicularis; Folusz - stream valley (FG-1041), 1954, leg. T. Sulma (UGDA; Kukwa 2005).

Umbilicaria deusta (L.) Baumg.

On sandstone rock; Diabli Kamień Mt. (FG-1041), 1936, leg. T. Sulma (UGDA; Polakowska 2002).

Umbilicaria hirsuta (Sw. ex Westr.) Hoffm.

On sandstone rock. Collecting site: 2.

Historical data: Diabli Kamień Mt. (FG-1041), Kornuty Reserve (EG-1969), 1936-62, leg. T. Sulma (UGDA; Sulma 1936; Śliwa \& Krzewicka 2002).

Usnea fulvoreagens (Räsänen) Räsänen

On bark of beech; Folusz - stream valley (FG-1041), 1955, leg. T. Sulma (UGDA; Polakowska 2002).

Usnea hirta (L.) Weber ex F. H. Wigg.

On wooden fence. Collecting site: 41.

Usnea intermedia (A. Massal.) Jatta

$U$. faginea Mot.

On bark of fir; Diabli Kamień Mt. (FG-1041), 1954, leg. T. Sulma (UGDA; Polakowska 2002).

\section{Usnea sp.}

On bark of linden. Collecting site: 42. 
Note. Identification of the species requires laboratory studies but the genus is legally protected; a sample could not be taken.

\section{Usnea wasmuthii Räsänen}

On bark of pine; Diabli Kamień Mt. (FG-1041), 1936, leg. T. Sulma (UGDA; Polakowska 2002).

\section{Varicellaria hemisphaerica (Flörke) Schmitt} \& Lumbsch

Pertusaria hemisphaerica (Flörke) Erichsen

On bark of fir, sycamore and beech. Collecting sites: 29, 31, 34.

Historical Data: Folusz - stream valley (FG-1041), Diabli Kamień Mt. (FG-1041), 1954-57, leg. T. Sulma (UGDA; Polakowska 2002); Skarpoty (FG-2079), Niedźwiedzie (FG-2180), 1979, leg. J. Nowak (KRAM).

Varicellaria lactea (L.) Schmitt \& Lumbsch

Pertusaria lactea (L.) Arnold

On boulder; Diabli Kamień Mt. (FG-1041), 1954, leg. T. Sulma (UGDA; Polakowska 2002).

\section{Verrucaria acrotella Ach.}

On boulder. Collecting site: 20. (!)

Note. This species is poorly distinguished due to its uncertain systematic status (Krzewicka 2012); so far it is unrecorded in the Polish Carpathians. It is known from the Western Carpathians in Slovakia (Bielczyk et al. 2004) and the Eastern Carpathians in Ukraine and Romania (Kondratyuk et al. 2003).

\section{Verrucaria aquatilis Mudd}

On boulder sprinkled with water. Collecting site: 40 .

Historical Data: Świerzowa Ruska (FG-2003), Nieznajowa (FG-2063); Rostajne (FG-2075); Czarne near Nieznajowa (FG-2082); Żydowskie (FG-2099); Krempna, by Wisłoka (FG-2152); Ostryszne near Krempna (FG-2153); Huta Krempska (FG-2162); Polany (FG-2186); Olchowiec, by Wilsznia river (FG2199), 1979, leg. J. Nowak (KRAM; Krzewicka 2009).

\section{Verrucaria dolosa Hepp}

On stones and concrete. Collecting sites: 33, 57.

Historical Data: Czarne near Nieznajowa (FG-2082), Ostryszne near Krempna (FG-2153), Krempna (FG2151), 1979, leg. J. Nowak (KRAM; Krzewicka 2009).

\section{Verrucaria elaeina Borrer}

On sandstone boulders in wet places; Majdan (FG-1093), Kotań (FG-2028), Czarne near Nieznajowa (FG-2082), Żydowskie (FG-2099), Krempna (FG-2152), Olchowiec, by Wilsznia river (FG-2199), 1979, leg. J. Nowak (KRAM; Krzewicka 2009).

Verrucaria elaeomelaena (A. Massal.) Arnold

On boulder in stream. Collecting site: 20 .

Historical Data: Huta Krempska (FG-2162), 1979, leg. J. Nowak (KRAM; Krzewicka 2009).

\section{Verrucaria hydrophila Orange}

$V$. denudata Zschacke, $V$. hydrela auct.

On rock by water and on wet stones. Collecting sites: 7,50 .

Historical Data: Olchowiec, by Wilsznia river (FG2199), Nieznajowa (FG-2063), 1979, leg. J. Nowak (KRAM; Krzewicka 2009, 2012)

\section{Verrucaria latebrosa Körb.}

On boulders and stones by stream; Bednarka Stream FG1928, Krempna (FG-2151), Huta Krempska (FG-2162), Wilsznia village (FG-2291), 1975-79, leg. J. Nowak (KRAM; Krzewicka 2009).

Verrucaria margacea (Wahlenb.) Wahlenb.

On boulders and stones by stream; Las Spełzły (FG2062), Olchowiec, by Wilsznia river (FG-2199), 1979, leg. J. Nowak (KRAM; Krzewicka 2012).

Verrucaria muralis Ach.

On concrete and boulder. Collecting sites: 5, 15, 33, 46. Historical data: Kotań (FG-2028), Nieznajowa (FG2064), Rostajne (FG-2075), Czarne near Nieznajowa (FG-2082), Ostryszne near Krempna (FG-2153), Wilsznia village (FG-2291), 1979, leg. J. Nowak (KRAM; Krzewicka 2009).

\section{Verrucaria murina Leight.}

V. myriocarpa Hepp.

On boulder. Collecting site: 20 .

Historical DATA: Huta Krempska (FG-2162), Ciechania (FG-3121), 1979, leg. J. Nowak (KRAM; Krzewicka 2009).

\section{Verrucaria nigrescens Pers.}

On concrete and stones. Collecting sites: 33, 43. 
Historical data: Ciechania (FG-3121), 1979, leg. J. Nowak (KRAM; Krzewicka 2009).

\section{Verrucaria obfuscans Nyl.}

On concrete. Collecting site: 33 .

\section{Verrucaria policensis Servít}

On stone by road. Collecting site: 33. (!)

Note. A species poorly known in Europe, reported only from the Czech Republic and Poland (Wyżyna Krakowsko-Częstochowska and Wyżyna Woźnicko-Wieluńska uplands) (Krzewicka 2012). The species is new for the Carpathians.

\section{Verrucaria praetermissa (Trevisan) Anzi}

On sandstone rock and boulder by stream, on wet stones and concrete. Collecting sites: 1, 4, 7, 12, 20, 40, 46, 50,53 .

Historical DATA: Świerzowa Ruska (FG-2003), Rostajne (FG-2074), Las Słodki (FG-2077), Czarne near Nieznajowa (FG-2082), Krempna, by Wisłoka river (FG-2152), Ostryszne near Krempna (FG-2153), Huta Krempska (FG-2162), Olchowiec, by Wilsznia river (FG-2199), 1979, leg. J. Nowak (KRAM; Krzewicka 2009).

\section{Verrucaria sublobulata Eitner ex Servít}

On wet sandstone and concrete. Collecting site: 35 .

Historical DATA: Żydowskie (FG-2097), 1979, leg. J. Nowak (KRAM; Krzewicka 2009).

\section{Verrucaria submersella Servít}

On stones in stream, on boulder and concrete. Collecting sites: $1,11,46$.

Verrucaria tectorum (A. Massal.) Körb.

On concrete. Collecting site: 33. (!)

Verrucaria viridula (Schrad.) Ach.

On stone. Collecting site: 5 .

Violella fucata (Stirt.) T. Sprib.

Mycoblastus fucatus (Stirt.) Zahlbr.

On bark of maple and sycamore. Collecting sites: 31 , 34,58 .

HistORICAL DATA: on bark of fir; Diabli Kamień Mt. (FG1041), 1957, leg. T. Sulma (UGDA; Polakowska 2002).
*Vouauxiella lichenicola (Linds.) Petr. \& Syd.

On Lecanora pulicaris (thallus and apothecia) growing on apple tree. Collecting site: 39. (!)

"Vouauxiomyces truncatus (B. de Lesd.) Dyko \& D. Hawksw.

On thallus of epiphytic Flavoparmelia caperata; Folusz - stream valley (FG-1041), 1954, leg. T. Sulma (UGDA; Kukwa 2005).

Vulpicida pinastri (Scop.) J.-E. Mattsson \& M. J. Lai On wooden fence, bark of pear tree and pine. Collecting sites: $39,41,50$.

Historical Data: Diabli Kamień Mt. (FG-1041), 1954, leg. T. Sulma (UGDA; Sulma \& Fałtynowicz 1988; Polakowska 2002).

Xanthoparmelia conspersa (Ach.) Hale

On sandstone. Collecting site: 2.

Historical data: Diabli Kamień Mt. (FG-1041), 1955, leg. T. Sulma (UGDA; Polakowska 2002); Rostajne (FG2074), 1979, leg. J. Nowak (KRAM; Bielczyk \& Kozik 2009).

Xanthoparmelia loxodes (Nyl.) O. Blanco, A. Crespo, Elix, D. Hawksw. \& Lumbsch Neofuscelia loxodes (Nyl.) Essl.

On boulder; Diabli Kamień Mt. (FG-1041), 1954-55, leg. T. Sulma (UGDA; Polakowska 2002).

Xanthoria parietina (L.) Th. Fr.

On bark of deciduous trees and on concrete. Collecting sites: 11, 27, 28, 29, 46.

HistoricAl DATA: Folusz - stream valley (FG-1041), 1954, leg. T. Sulma (UGDA; Polakowska 2002).

Xylographa parallela (Ach.: Fr.) Behlen \& Desberger $X$. abietina (Pers.) Zahlbr.

On decaying stump; Rostajne (FG-2074), 1979, leg. J. Nowak (KRAM).

Xylopsora caradocensis (Leight. ex Nyl.)

Bendiksby \& Timdal

Hypocenomyce caradocensis (Leight. ex Nyl.) P. James \& Gotth. Schneid.

On bark of fir and beech, on wood. Collecting sites: $15,16,17,44$.

Historical data: Skarpoty (FG-2079), 1979, leg. 
J. Nowak (KRAM; Bielczyk 2003; Bielczyk \& Kozik 2009).

Zwackhia viridis (Ach.) Poetsch \& Schied.

Opegrapha viridis (Ach.) Behlen \& Desberger

On bark of beech; Folusz - stream valley (FG-1041), 1957, leg. T. Sulma (UGDA; Polakowska 2002).

\section{DISCUSSION}

The number of species of lichens and allied fungi reported from Magurski National Park, 337, is significant though lower than in other Carpathian national parks, for example Gorce National Park (Czarnota 2010) or Bieszczady National Park (Kościelniak 2013). The lower diversity of the lichen biota there is connected with natural conditions such as the low elevation of the hills and the low variability of geological substrate, including the absence of limestone. It should be noted, however, that lichenological research in the Beskid Niski Mts was not as comprehensive as in the two national parks mentioned.

As a result of the 2009 fieldwork, 112 species were reported as new for MNP, including 75 new for the Beskid Niski range; these include (1) species recently described as new to science, (2) rather inconspicuous species easily overlooked in the field, and (3) species that require the application of modern methods for their identification. Of the newly reported taxa, 15 species are fungi allied with lichens, which in recent years have been a subject of more intensive lichenological research.

The presented results enrich our knowledge of the species diversity and distribution of lichens not only in the Carpathians but also in Poland. Two lichenicolous fungi, Intralichen lichenicola and Burgoa angulosa, are reported here as new for Poland and indeed for the Carpathians; both species are known from only a few localities in Europe (Hawksworth \& Cole 2002; Diederich \& Lawrey 2007). The record of Verrucaria policensis from the vicinity of Nieznajowa is new for the Carpathians; it is poorly known in Europe and recorded only from the Czech Republic and Poland (Wyżyna Woźnicka and Wyżyna Olkuska uplands) (Krzewicka 2012). Fuscidea arboricola is new for the Western Carpathians; it is known from a few localities in the Eastern Carpathians in Slovakia, Ukraine (Kondratyuk et al. 2003; Coppins et al. 2005) and Romania (Ardelean et al. 2013), so its locality on Kamień Mt. extends its western range. Halecania viridescens, a species so far reported only from the north of Poland (Kukwa \& Jabłońska 2009; Schiefelbein et al. 2012), is newly recorded for the Polish Carpathians, as is Mycomicrothelia confusa, a species known in Poland only from $19^{\text {th }}$-century reports from the Sudetes (Fałtynowicz 2003). Epigloea urosperma, a lichenicolous fungus, has its second locality in the Carpathians, in addition to Babia Góra Massif (Czarnota \& Hernik 2013). Rinodina griseosoralifera is a species known in Poland only from the Gorce Mts (Czarnota \& Kukwa 2007) and in the Carpathians only from its eastern part situated in Ukraine (Coppins et al. 2005). Other very rare species in Poland recorded for the second time in the Polish Carpathians are Absconditella pauxilla, a species found in one locality in the Tatras (Czarnota 2012); Collema crispum, known from the Góry Słonne Mts (Kiszka \& Piórecki 1992); and Licea parasitica, collected in the Kotlina OrawskoNowotarska basin (Kukwa \& Jabłońska 2008).

Two species of a small group of lichenicolous basidiomycetes deserve attention. Dictyocatenulata alba was found in a shady Dentario glandulosaeFagetum community in two localities: stream valleys of Baranie and Olchowczyk. Previously it was known only from the Gorce Mts in Poland, besides the Western Carpathians in Slovakia and the Eastern Carpathians in Slovakia and Ukraine (Diederich et al. 2008). The other species, Multiclavula mucida, had been reported from only one locality in the Polish lowland (Czyżewska et al. 2005) and three localities in the Bieszczady Mts (Kościelniak 2013).

The lichenological importance of Magurski National Park is emphasized by the presence of some rare and interesting species, eight of which are under strict legal protection (Montanelia disjuncta, Normandina pulchella, Parmelia omphalodes, P. submontana, Parmelina tiliacea, Peltigera praetextata, Punctelia jeckeri, Ramalina fraxinea) and four of which are under partial 
protection (Hypogymnia tubulosa, Imshaugia aleurites, Usnea hirta, Vulpicida pinastri). The park also contains a significant number of nationally red-listed species (Cieśliński et al. 2006), including 37 threatened ones (Table 1). Many of these have ecological niches in MNP area which ensure their survival, making the park an important refuge for numerous lichen species endangered in the country. Moreover, the strategy of nature protection adopted in MNP (Szafrański 2009) gives some positive perspective for the development of favorable conditions for lichens in the future.
Unfortunately, the process of lichen impoverishment which has intensified since the mid $20^{\text {th }}$ century can also be observed in MNP. At present, 94 species reported by T. Sulma from MNP in the 1930s, 1950s and 1960s and by J. Nowak in the 1960s and 1970s have not been refound. The number includes species with tiny, inconspicuous thalli, which may have been overlooked, but mainly these are rare species, such as Cryptodiscus gloeocapsa, Thelopsis rubella, Thelocarpon magnussonii and lichenicolous fungi. The fact that others were not refound may be due to confusion resulting from their external similarity to other

Table 1. Species of Magurski National Park included in the red list of lichens in Poland.

\begin{tabular}{|c|c|c|c|}
\hline $\begin{array}{l}\text { Threat } \\
\text { category }\end{array}$ & & Name of species & $\begin{array}{l}\text { Number } \\
\text { of species }\end{array}$ \\
\hline \multirow[t]{2}{*}{$\mathrm{CR}$} & Present & Bacidina egenula & 1 \\
\hline & Not confirmed & $\begin{array}{l}\text { Bryoria capillaris, Chrysothrix candelaris, Evernia divaricata, E. mesomorpha, } \\
\text { Gyalecta ulmi, Menegazzia terebrata, Nephroma parile, Usnea fulvoreagens, U. in- } \\
\text { termedia, U. wasmuthii }\end{array}$ & 10 \\
\hline \multirow[t]{2}{*}{$\mathrm{EN}$} & Present & $\begin{array}{l}\text { Arthonia atra, Bacidia subincompta, Chaenotheca brunneola, Ch. phaeocephala, } \\
\text { Ch. stemonea, Cladonia caespiticia, Cl. parasitica, Loxospora elatina, Normandina } \\
\text { pulchella, Parmelia omphalodes, Ramalina fraxinea }\end{array}$ & 11 \\
\hline & Not confirmed & $\begin{array}{l}\text { Anaptychia ciliaris, Caloplaca cerinella, Flavoparmelia caperata, Lecanora albella, } \\
\text { Opegrapha vermicellifera, Physconia distorta, Ramalina fastigiata, R. obtusata, Rhi- } \\
\text { zocarpon grande, Verrucaria latebrosa, Xylographa paralella }\end{array}$ & 12 \\
\hline \multirow[t]{2}{*}{ VU } & Present & $\begin{array}{l}\text { Acrocordia gemmata, Bacidia rubella, Biatora efflorescens, Calicium viride, Chae- } \\
\text { notheca xyloxena, Hydropunctaria rheitrophila, Melanohalea elegantula, Montanelia } \\
\text { disjuncta, Ochrolechia androgyna, Opegrapha niveoatra, Parmelia submontana, } \\
\text { Parmelina tiliacea, Peltigera praetextata, Pyrenula nitida, Rhizocarpon badioatrum, } \\
\text { Rinodina exigua, Umbilicaria hirsuta, Usnea hirta, Varicellaria hemisphaerica, Ver- } \\
\text { rucaria aquatilis, } V . \text { hydrophila, } V . \text { viridula }\end{array}$ & 22 \\
\hline & Not confirmed & $\begin{array}{l}\text { Aspicilia laevata, Caloplca cerina, Cetraria chlorophylla, C. islandica, Cladonia macro- } \\
\text { ceras, Cryptodictus gloeocapsa, Diploschistes gypsaceus, Lecanora sulphurea, Ochrole- } \\
\text { chia arborea, Opegrapha rufescens, Pertusaria aspergilla, P. coronata, P. pertusa, } \\
\text { Punctelia subrudecta, Ramalina farinacea, R. pollinaria, Stereocaulon vesuvianum, } \\
\text { Verrucaria margacea, Zwackhia viridis }\end{array}$ & 19 \\
\hline \multirow[t]{2}{*}{ NT } & Present & $\begin{array}{l}\text { Alyxoria varia, Arthothelium ruanum, Bacidina arnoldiana, Chaenotheca furfuracea, } \\
\text { Ch. trichialis, Dibaeis baeomyces Evernia prunastri, Graphis scripta, Hypogymnia } \\
\text { tubulosa, Lecidella scabra, Leimonis erratica, Thelidium minutulum, V. praetermissa, } \\
\text { Vulpicida pinastri }\end{array}$ & 14 \\
\hline & Not confirmed & $\begin{array}{l}\text { Acarospora umbilicata, Pertusaria coccodes, P. leioplaca, P. pupillaris, Physcia } \\
\text { aipolia, Polysporina subfuscescens, Protoparmelia badia, Tephromela atra, Trape- } \\
\text { liopsis viridescens }\end{array}$ & 9 \\
\hline \multirow[t]{2}{*}{$\mathrm{LC}$} & Present & Porpidia macrocarpa, Psilolechia lucida, Strangospora pinicola, Thelocarpon epibolum & 4 \\
\hline & Not confirmed & Umbilicaria deusta, Varicellaria lactea & 2 \\
\hline \multirow[t]{2}{*}{ DD } & Present & $\begin{array}{l}\text { Lecanora persimilis, Punctelia jeckeri, Schaereria fuscocinerea, Verrucaria murina, } \\
\text { V. sublobulata }\end{array}$ & 5 \\
\hline & Not confirmed & Cladonia macrophyllodes, Ionaspis ceracea, Thelocarpon robustum, Thelopsis rubella & 4 \\
\hline
\end{tabular}


species, as in the case of Verrucaria elaeina, which is likely to be confused with $V$. muralis. However, many previously reported lichens, especially epiphytic and wood-inhabiting species, should now be considered extinct or at least very rare; 56 of them are red-listed in Poland (e.g., Anaptychia ciliaris, Bryoria capillaris, Chrysothrix candelaris, Evernia divaricata, E. mesomorpha, Flavoparmelia caperata, Lecanora albella, Menegazzia terebrata, Nephroma parile, Punctelia subrudecta, Usnea fulvoreagens, U. intermedia, U. wasmuthii) (Table 1). These species are particularly sensitive to all kinds of habitat disturbances, especially air pollution, which is considered the main reason for their extinction. Another factor responsible for the elimination of some species could be changed light conditions in localities formerly rich in lichens, as for example Diabli Kamień rock, where two saxicolous species, Stereocaulon vesuvianum and Umbilicaria deusta, became extinct.

Anthropogenic factors do not always have a negative impact on lichen biota. Many species in MNP occur frequently or exclusively in secondary habitats such as abandoned villages where epilithic lichens grow on walls of old churches, graveyards, outbuildings and old bridges. This group includes Acarospora moenium, Lecanora crenulata, L. hagenii, Lecidella stigmatea, Rinodina oleae, Rusavskia elagans and Trapelia placodioides, as well as representatives of the genera Caloplaca and Verrucaria. Among the numerous epiphytes recorded on single trees, the following are worth mentioning: Alyxoria varia, Arthonia atra, Biatora chrysantha and Normandina pulchella. These species are usually confined to forest habitats but they are also found in old orchards or groves in churchyards, etc. Colonization of forest lichen species in anthropogenic habitats as a result of habitat restoration is well documented in the Bieszczady Mts, a region neighboring the Beskid Niski Mts (Kościelniak 2004, 2013).

On the basis of the presented results, we conclude that Magurski National Park is of great lichenological importance and worthy of protection. Its incorporation into the European Natura 2000 network as the Ostoja Magurska habitat refuge contributes to the preservation of lichen diversity and protection of critical species, especially those sensitive to human impacts. As a consequence of environmental improvement, some species that have disappeared from MNP can be expected to return.

ACKNOWLEDGEMENTS. We are grateful to the management and staff of Magurski National Park for their kind assistance and involvement in the organization of the $24^{\text {th }}$ Meeting of Polish Lichenologists, as well as their help with the field research, Mark R. D. Seaward and the anonymous reviewer for helpful comments and corrections of the manuscript, and Paul Diederich (Luxembourg) for identifying Burgora angulosa. The study was supported from statutory fund of the W. Szafer Institute of Botany, Polish Academy of Sciences.

\section{REFERENCES}

Ardelean I. V., Keller C. \& Scheidegger C. 2013. Lichen flora of Rodnei Mountains National Park (Eastern Carpathians, Romania) including new records for the Romanian mycoflora. Folia Cryptog. Estonica 50: 101-115.

ARUP U. 2006. A new taxonomy of the Caloplaca citrina group in the Nordic countries, except Iceland. Lichenologist 38: $1-20$.

Arup U. 2009. The Caloplaca holocarpa group in the Nordic countries, except Iceland. Lichenologist 41: 111-130.

BIELCZYK U. 2002. Diploschistes gypsaceus (Ach.) Zahlbr. In: U. BielczyK, S. CieślińsKi \& W. FAltynowicz (eds), Atlas of the geographical distribution of lichens in Poland 3: 39-46. W. Szafer Institute of Botany, Polish Academy of Science, Kraków.

BIELCZYK U. 2003. The lichens and allied fungi of the Western Carpathians. In: U. BIELCZYK (ed.), The lichens and allied fungi of the Polish Carpathians - an annotated checklist, pp. 23-232. W. Szafer Institute of Botany, Polish Academy of Sciences, Kraków.

BielczyK U. \& KozIK R. 2009. Porosty Magurskiego Parku Narodowgo. In: A. Górecki \& B. ZeMANEK (eds), $M a-$ gurski Park Narodowy - monografia przyrodnicza, pp. 86-95. Magurski Park Narodowy, Uniwersytet Jagielloński, Krempna-Kraków.

BielCZYK U., LaCKovičová A., FARKas E., LöKÖS L., Breuss O. \& Kondratyuk S. YA. 2004. Checklist of lichens of the Western Carpathians. W. Szafer Institute of Botany, Polish Academy of Sciences, Kraków.

CieŚliński S., CZyżewsKa K. \& FABISZEwSKi J. 2006. Red List of the lichens in Poland. In: Z. MireK, K. ZARZYCKI, W. WoJEWoda \& Z. SzeląG (eds), Red list of plants and fungi in Poland, pp. 71-89. W. Szafer Institute of Botany, Polish Academy of Sciences, Kraków. 
Coppins B. J. 1989. Rinodina griseosoralifera, a new corticolous sorediate lichen from Western Europe. Lichenologist 21: 169-186.

Coppins B. J. \& van Den Boom P. P. G. 2002. Bacidia brandii, a new lichen species from the Netherlands, Belgium, France and Lithuania. Lichenologist 34: 327-332.

Coppins B. J., Kondratyuk S. Ya., Khodosovtsev A. Ye., Zelenko S. D. \& Wolseley P. A. 2005. Contribution to lichen flora of Ukrainian Carpathians. Chornomors 'kyi Botanichnyi Zhurnal 1: 5-23.

Czarnota P. 2007. The lichen genus Micarea (Lecanorales, Ascomycota) in Poland. Polish Bot. Stud. 23: 1-199.

Czarnota P. 2010. Critical list of lichens and lichenicolous fungi of the Gorce Mts. Ochrona Beskidów Zachodnich 3: 55-78 (in Polish with English summary)

Czarnota P. 2012. New records of lichenized and lichenicolous fungi from Tatra National Park (W. Carpathians). In: L. LIPNICKI (ed.), Lichen protection - Lichen protected species, pp. 287-300. Sonar Literacki, Gorzów Wlkp.

Czarnota P. \& Coppins B. J. 2000. A new species of Agonimia and some interesting lichens from Gorce Mts (Western Beskidy Mts) new to Poland. Graphis Scripta 11: 56-60.

Czarnota P. \& Coppins B. J. 2006. A new Bacidia with longnecked pycnidia from central Europe. Lichenologist 38: 407-410.

Czarnota P. \& Coppins B. J. 2007. Contribution to the knowledge of rare Bacidia s.lat. (Lecanorales, lichenized Ascomycetes) from Central Europe including a new, pallid forma of Bacidia hemipolia. Nova Hedwigia 85: 503-513.

Czarnota P. \& Hernik E. 2013. Notes on two Epigloea species from Central Europe. Acta Soc. Bot. Poloniae 82: 321-324.

Czarnota P. \& Hernik E. 2014. Some peltigericolous microlichens from southern Poland. Acta Bot. Croat. 73: 159-170.

Czarnota P. \& Kunwa M. 2004. Some sorediate lichens and lichenicolous fungi new to Poland. Graphis Scripta 15: 24-32.

Czarnota P. \& Kukwa M. 2007. Rinodina griseosoralifera, a lichen species new to the Western Carpathians. Acta Mycol. 42: 287-290.

Czarnota P. \& Węgrzyn M. 2012. Lichenized and lichenicolous fungi new to Babia Góra National Park (Poland, Western Carpathians). Mycotaxon 122: 89-110.

Czyżewska K. \& KuKwa M. 2009. Lichenicolous fungi of Poland. A catalogue and key to species. W. Szafer Institute of Botany, Polish Academy of Sciences, Kraków.

Czyżewska K., Motiejūnaitė J. \& CieśLińsKi S. 2005. New and noteworthy species of lichens and allied fungi from North-Eastern Poland. Acta Mycol. 40: 277-291.

Diederich P. \& Lawrey J. D. 2007. New lichenicolous, muscicolous, corticolous and lignicolous taxa of Burgoa s.l. and Marchandiomyces s.1. (anamorphic Basidiomycota), a new genus for Omphalina foliacea, and a catalogue and a key to the non-lichenized bulbilliferous basidiomycetes. Mycol. Progr. 6(2): 61-80.

Diederich P., Palice Z. \& ErTz D. 2008. Cheiromycina ananas is a synonym of Dictyocatenulata alba, a widespread, lichenized, synnematous hyphomycete herewith reported as new for Europe. Sauteria 15: 205-214.

Dymytrova L., Nadyeina O., Naumovych A., Keller C. \& Scheidegger C. 2013. Primeval beech forests of Ukrainian Carpathians are sanctuaries for rare and endangered epiphytic lichens. Herzogia 26: 73-89.

Faltynowicz W. 1999. Normandina pulchella (Borrer) Nyl. In: S. CIEŚLiŃski \& W. FAltynowiCZ (eds), Atlas of the geographical distribution of lichens in Poland 2: 39-45. W. Szafer Institute of Botany, Polish Academy of Science, Kraków.

FaŁTYNOWICZ W. 2003. Lichens, lichenicolous and allied fungi of Poland. An annotated checklist. W. Szafer Institute of Botany, Polish Academy of Sciences, Kraków.

Flakus A. \& KuKwa M. 2009. Additions to the biota of lichenized fungi of Poland. Acta Mycol. 44: 249-257.

Górecki A. \& Zemanek B. (eds) 2009. Magurski Park Narodowy - monografia przyrodnicza. Magurski Park Narodowy, Uniwersytet Jagielloński, Krempna - Kraków.

Guttová A. \& Palice Z. 1999. Lichens of National Park Muránska planina I -the Hrdzavá dolina Valley. In: M. UHRIN (ed.), Výskum a ochrana prírody Muránskej planiny. 2: 35-47. MŽP SR Bratislava a Správa NP Muránska planina, Revúca (in Slovak with English summary).

Guttová A., Palice Z., Czarnota P., Halda J. P., Lukač M., MALIČEK J. \& Blanár D. 2012. Lichens of the Muránska Planina National Park IV - Fabova hol'a. Přir. Sborn. Slov. Muz. 58: 51-75 (in Slovak with English summary).

Hawksworth D. L. \& Cole M. S. 2002. Intralichen a new genus for lichenicolous, 'Bispora' and 'Trimmatostroma' species. Fungal Diversity 11: 87-97.

Hawksworth D. L. \& Orange A. 2009. Mycomicrothelia Keissl. (1936). In: C. W. Smith, A. Артroot, B. J. CopPins, A. Fletcher, O. L. Gilbert, P. W. James \& P. A. Wolseley (eds), The lichens of Great Britain and Ireland, pp. 619-620. British Lichen Society, London.

KaLB K. 2007. New or otherwise interesting lichens. Biblioth. Lichenol. 95: 297-316.

KisZKa J. \& PióRECKI J. 1992. The lichens of the Stonne Mts in the Polish Eastern Carpathians. Wydawnictwo Zakładu Fizjografii i Arboretum w Bolestraszycach, Bolestraszyce (in Polish with English summary).

Kocourcová J., Knudsen K. \& Tucker S. 2012. A checklist of the licheniclous biota of California. Opuscula Philolichenum 11: 64-103.

Kondracki J. 1989. Karpaty. Wydawnictwo Szkolne i Pedagogiczne, Warszawa. 
Kondratyuk S. Ya., Popova L. P., Lackovičová A. \& Pišút I. 2003. A catalogue of the Eastern Carpathian lichens. M. H. Kholodny Institute of Botany NAS of Ukraine, Institute of Botany SAS, Kiev - Bratislava.

KoŚCIELniaK R. 2004. The Lichens of the Bieszczady Niskie Mts. Fragm. Flor. Geobot. Polon., Suppl. 5: 3-164 (in Polish with English summary).

KościelniaK R. 2013. Lichens of the Bieszczady National Park - present state and changes in the last 50 years. Monografie Bieszczadzkie 14: 5-602.

KościelniaK R. \& KiszKa J. 2003. The lichens and allied fungi of the Polish Eastern Carpathians. In: U. BIELCZYK (ed.), The lichens and allied fungi of the Polish Carpathians - an annotated checklist, pp. 235-294. W. Szafer Institute of Botany, Polish Academy of Sciences, Kraków.

Kowalewska A. \& KuKwa M. 2013. Lichens, lichenicolous and resinicolous fungi of the 'Buki Mierzei Wiślanej' nature reserve (N Poland). Acta Botanica Cassubica 12: 67-79 (in Polish with English summary).

KrzewickA B. 2009. Some new records of Verrucaria from Beskid Niski Mts. Acta Mycol. 44: 265-273.

KrzewickA B. 2012. A revision of Verrucaria s.1. (Verrucariaceae) in Poland. Polish. Bot. Stud. 27: 3-143.

Kubiak D. \& Sparrius L. B. 2004. Bacidia adastra, B. brandii and $B$. neosquamulosa found in North-Eastern Poland. Graphis Scripta 16: 61-64.

Kubiak D. \& Westberg M. 2011. First records of Candelariella efflorescens (lichenized Ascomycota) in Poland. Polish Bot. J. 56: 315-319.

Kukwa M. 2005. New or interesting records of lichenicolous fungi from Poland III. Herzogia 18: 37-46.

Kunwa M. 2011. The lichen genus Ochrolechia in Europe. Fundacja Rozwoju Uniwersytetu Gdańskiego, Gdańsk.

Kukwa M. \& Czarnota P. 2006. New or interesting records of lichenicolous fungi from Poland IV. Herzogia 19: 111-123.

Kukwa M. \& Diederich P. 2005. Monodictys epilepraria, a new species of lichenicolous hyphomycetes on Lepraria. Lichenologist 37: 217-220.

KuKwa M. \& Flakus A. 2009. New or interesting records of lichenicolous fungi from Poland VII. Species mainly from Tatra Mountains. Herzogia 22: 191-211.

Kukwa M. \& JabŁońsKa A. 2008. New or interesting records of lichenicolous fungi from Poland VI. Herzogia 21: 167-179.

KuKwa M. \& JABŁoŃSKA A. 2009. New records of two crustose sorediate lichens from central Europe. Mycotaxon 107: 375-381.

KuKWA M. \& ZDUŃCZYK A. 2011. New localities of rare and interesting lichens from the Pomorze Gdańskie and adjacent areas. Acta Botanica Cassubica 10: 59-73 (in Polish with English summary).
Kunwa M., Czarnota P. \& Perz P. 2010. New or interesting records of lichenicolous fungi from Poland VIII. Herzogia 23: $111-119$.

Kukwa M., Kowalewska A., Śliwa L., Czarnota P., CzyżewSKa K., Flakus A., KubiaK D., Wilk K., Dimos-Zych M., Kolanko K., SzymczyK R., Lipnicki L., AdAmska E., Bielec D., Guzow-KrzemińsKa B., GruszKa W., HaChUŁKa M., JabŁońSKa A., Oset M., KisZKa J., KoziK J., LEŚNIAŃSKI G. \& LAZARUS M. 2013. Lichens and lichenicolos fungi of the Wdzydzki Landscape Park (Pomorze Gdańskie, N Poland). Acta Botanica Cassubica 11: 75-103 (in Polish with English summary).

LEŚNIAŃSKI G. 2002. Acarospora glaucocarpa (Ach.) Körb. In: U. BIELCZYK, S. CIEŚLIŃSKI \& W. FALTYNOWICZ (eds), Atlas of the geographical distribution of lichens in Poland 3: 7-14. W. Szafer Institute of Botany, Polish Academy of Science, Kraków.

LisıckÁ E. 2005. The lichens of the Tatry Mountains. Veda, Bratislava.

LubeK A. 2009. New records of lichens from the Polish uplands. Acta Mycol. 44: 275-282.

ŁUBEK A. 2012. A profile of lichen diversity down the trunk of common ash (Fraxinus excelsior) highlights its importance in maintaining lichen species diversity in the Oleszno reserve (Przedborski Landscape Park). Leśne Prace Badawcze 73: 23-32 (in Polish with English summary).

ŁubeK A. \& JAROSZEwiCZ B. 2012. New, rare and noteworthy species of lichens and lichenicolous fungi from Białowieża Forest. Polish J. Nat. Sci. 27: 275-287.

Mотүка J. 1927. Études sur les associations des lichens établies, sur les troncs des arbres aux environs de Grybów. Une contribution à la connaissance des types des forêts des Carpathes. Sylwan 45: 1-14, 73-84 \& 141-148 (in Polish with French summary).

Nowak J. 1983. Porosty (Lichenes). 1.1. Państwowe Wydawnictwo Naukowe, Warszawa - Kraków.

NowaK J. 1993. Porosty (Lichenes). 6.3. Physciaceae sensu stricto. Polska Akademia Nauk, Instytut Botaniki im. W. Szafera, Kraków.

NowaK J. 1995. Lichenes Poloniae Meridionalis Exsiccati ab Instituto Botanico Academiae Scientiarum Polonae editi. Fasc. IX-X (no. 201-250). Cracoviae.

NowaK J. 1998. Porosty (Lichenes), 6.2. Buelliaceae (Physciaceae sensu lato). Flora polska. Rośliny zarodnikowe Polski i ziem ościennych. Polska Akademia Nauk, Instytut Botaniki im W. Szafera, Kraków.

Olech M. 1974. Materials to the lichen flora of the Beskid Niski Mts. (Western Carpathians). Zesz. Nauk. Uniw. Jagiellon. Prace Bot. 2: 181-200 (in Polish with English summary).

Orange A., James P. W. \& White F. J. 2010. Microchemical 
methods for the identification of lichens. British Lichen Society, London.

Polakowska A. 2002. Porosty i grzyby naporostowe „Diablego Kamienia" $i$ doliny potoku Folusz w Beskidzie Niskim. Praca magisterska wykonana w Katedrze Taksonomii Roślin i Ochrony Przyrody Uniwersytetu Gdańskiego, Gdańsk.

Purvis O. W. \& James P. W. 2009. Lecidella Körb. (1855). In: C. W. Smith, A. Aptroot, B. J. Coppins, A. Fletcher, O. L. Gilbert, P. W. JAMES \& P. A. Wolseley (eds), The lichens of Great Britain and Ireland, pp. 519-529. British Lichen Society, London.

Schiefelbein U., Czarnota P., Thüs H. \& Kukwa M. 2012. The lichen biota of the Drawieński National Park (NW Poland, Western Pomerania). Folia Cryptog. Estonica 49: 59-71.

Śliwa L. 2010. Contribution to the lichen biota of the Pogórze Wiśnickie foothills (Carpathians). Acta Mycol. 45: 219-230.

Śliwa L. \& Krzewicka B. 2002. Umbilicaria hirsuta (Sw. ex Westr.) Hoffm. In: U. BIELCZYK, S. CIEŚLIŃSKI \& W. FALTYNOWICZ (eds), Atlas of the geographical distribution of lichens in Poland 3: 95-100. W. Szafer Institute of Botany, Polish Academy of Science, Kraków.

ŚLIWA L. \& KuKWA M. 2012. New distribution data for sterile crustose lichens in then Polish Tatra Mts and its surroundings. Polish Bot. J. 57: 259-278.

Šoun J., Vondrák J., Søchting U., Hrouzek P., KhodoSOVTSEV A. \& ARup U. 2011. Taxonomy and phylogeny of the Caloplaca cerina group in Europe. Lichenologist 43: 113-135.

Sulma T. 1936. Kornuty bei Gorlice als Naturschutzgebiet (Pinus mughus Scop.) in den Beskiden. Ochr. Przyr. 16: 57-73 (in Polish with German summary).

Sulma T. \& Faltynowicz W. 1988. Materials on distribution of lichens of the family Parmeliaceae in Poland. Acta Mycol. 23: 107-123 (in Polish with English summary).

SzAFRAŃSKI J. 2009. Strategia ochrony zasobów przyrodniczych. In: A. GóRecki \& B. ZEMANEK (eds), Magurski Park Narodowy - monografia przyrodnicza, pp. 262-264. Magurski Park Narodowy, Uniwersytet Jagielloński, Krempna-Kraków.

Urbanavichene I. \& Urbanavichus G. 2014. Bacidia pycnidiata discovered in European Russia. Folia Cryptog. Estonica 51: 109-111.

Vondrák J., Palice Z., Khodosovtsev A. \& Postoyalkin S. 2010a. Additions to the diversity of rare or overlooked lichens and lichenicolous fungi in Ukrainian Carpathians. Chornomors 'kyi Botanichnyi Zhurnal 6: 6-34.

Vondrák J., Halda J. P., Malíčé J. \& Müller A. 2010 b. Lichens recorded during the spring bryo-lichenological meeting in Chřiby Mts (Czech Republic), April 2010. Bryonora 45: 36-42.

WILK K. 2012. Calcicolous species of the genus Caloplaca in the Polish Western Carpathians. Polish Bot. Stud. 29: 1-92.

ZAJĄC A. 1978. Atlas of distribution of vascular plants in Poland (ATPOL). Taxon 27: 481-484. 